\title{
Mixing processes in lakes: mechanisms and ecological relevance ${ }^{1}$ )
}

\author{
By D. M. Imboden, U. Lemmin, T. Joller and M. Schurter \\ Swiss Federal Institute for Water Resources and Water Pollution Control (EAWAG) at Swiss Federal \\ Institutes of Technology (ETH)
}

Manuscript received on 5 May 1983

\begin{abstract}
In Lake Baldegg, Switzerland (surface area $5.3 \mathrm{~km}^{2}$, maximum depth $66 \mathrm{~m}$ ) the analysis of data from moored instrument systems (atmospheric boundary layer, lake temperature distribution, bottom currents) was correlated to the long-term development of vertical mixing as seen from profiles of natural isotopes (radon-222, tritium and helium-3) and chemical species. The investigation shows: I. Vertical mixing coefficients below $25 \mathrm{~m}$ are small. Consequently the vertical concentration distribution of sediment emanating species in the deep hypolimnion is controlled by the bottom topography. 2. Renewal of deep hypolimnic water is significant even during stratification. 3. Weakly damped internal waves characterize the internal dynamics during stratification. 4. Horizontal bottom currents play an important role in the hypolimnion mixing and can be correlated to internal waves during stratification.
\end{abstract}

\section{Introduction}

In the industrialized countries eutrophication - and its link to phosphorus - has been identified as one of the major pollution problems of lakes [28]. Early attempts to quantify the process of eutrophication and to compare it among different lakes focussed upon simple mass balance concepts relating phosphorus input and inlake concentration. In this regard, Vollenweider's [35] empirical relationship between mean lake depth, P-loading per unit lake surface, and trophic state set a milestone and stimulated others to employ similar ideas.

After the first euphoria over the new concepts, those cases which did not fit into the general picture began to raise interest. It was recognized that spatial heterogeneity, that is incomplete mixing of chemical and biological constituents within the lake, represents one important cause for the resistance of lakes to eutrophication $[9,10$, 30]. Conditions which favor the occurrence of partially mixed water bodies are due to large point sources (rivers, outlets, etc.), mass flux across the sediment-water interface (particularly under anoxic conditions), and meromictic mixing.

Furthermore, the fast and cheap calculation of tolerable phosphorus, made possible for a large number of lakes by Vollenweider's approach, brought along the disillu-

1) Supported by the Swiss National Science Foundation within the framework of its National Research Program on 'Fundamental problems of the water cycle in Switzerland'. 
sionizing result that the reduction of external point sources of phosphorus alone could not return all lakes to an oligotrophic - or at least mesotrophic - state [1]. Hence, a combination of external and internal pollution control measures had to be developed for those lakes for which sewage diversion alone would not solve the problem [15]. Since internal measures, such as artificial destratification, aeration or diversion of hypolimnic water, would often interfere with the mixing regime of the lake, better understanding of natural mixing mechanisms became urgent. Also, the study of possible synergetic effects between physical and chemical perturbations of lakes became important. Examples for activities which may alter mixing structures are input of waste heat, export of heat for heat pump operation [5], and pumped storage power operation between lakes [11].

Such was the situation in 1976, when the Swiss National Science Foundation (SNF) initiated a National Program on Water Research. The study of mixing processes in lakes was identified as a field deserving a special research effort. The Swiss Federal Institute for Water Resources and Water Pollution Control (EAWAG) decided to focus its project on the vertical mixing mechanisms which seemed to us to be of particular importance in order to link lake physics and trophic state. Indeed, a preliminary study on Greifensee (Switzerland), using radon-222 as natural tracer [14], had identified vertical mixing across the thermocline to be a significant source of phosphorus to the productive layer at the lake surface.

In 1977, when our research program was started we thought that the radon technique which was successfully employed in Greifensee to evaluate hypolimnic vertical mixing could also be used in other lakes. Later however, measurements revealed a different situation: In some lakes the natural level of radon-222 was simply too low to allow for the measurement of activity profiles (Lake Zürich, Lake Baldegg); in other lakes the three-dimensional mixing and bottom topography prohibited the unique evaluation of mixing parameters from radon alone (Lake Lucerne, Lake Brienz). More details are presented in chapter 3.

Therefore, we decided to abandon part of the original plan (the simultaneous study of several lakes with different mixing and trophic properties) and to concentrate our effort on just one lake in which more than one method for the evaluation of mixing phenomena could be employed. With Lake Baldegg (table 1), private property of the Swiss Federation for Nature Protection, we found an ideal playground where the anchorage of buoys for recording instruments did not pose those problems common on public lakes.

The general philosophy and the different techniques applied in Lake Baldegg are described in chapter 2 . In chapter 3 - the only one referring to measurements from

Table 1. Characteristics of Lake Baldegg (Switzerland). For map see figure 6.

\begin{tabular}{ll}
\hline Surface area & $5.3 \mathrm{~km}^{2}$ \\
Drainage area (without lake surface) & $68.4 \mathrm{~km}^{2}$ \\
Volume of lake & $1.8 \times 10^{8} \mathrm{~m}^{3}$ \\
Mean depth & $34 \mathrm{~m}$ \\
Maximum depth & $66 \mathrm{~m}$ \\
Mean outflow & $1.3 \mathrm{~m}^{3} \mathrm{~s}^{-1}$ \\
Mean residence time of water & $4.4 \mathrm{yr}$ \\
\hline
\end{tabular}


other lakes - mixing coefficients calculated from the distribution of natural tracers are presented. Mixing coefficients calculated from temperature data are given in chapter 4 . Chapter 5 deals with internal wave dynamics, and bottom currents are discussed in chapter 6 .

This work has been financially supported by the Swiss National Science Foundation. Cooperation with the other contributors to the National Research Program on Lake Currents was stimulating and helpful: We specially mention the Lake Research Group at the Laboratory of Hydraulics, Hydrology and Glaciology (VAW) of the Federal Institute of Technology in Zürich which supported our field work by both personal and instrumental means; with the lake group at the Institute of Inorganic Chemistry at the University in Bern we fruitfully shared interest in isotope techniques and ecological lake modelling. Members of the Amt für Gewässerschutz of the Canton of Lucerne (where Lake Baldegg is located), of the Swiss Federation for Nature Protection, owner of Lake Baldegg, and particularly the tolerance of the lake's only professional fisherman, A. Hofer, made our field work easy and rich. The list of names appearing as the authors of this article does not reward everybody who indirectly contributed to its content: Our research profitted from the continuous support from the director of EAWAG, W. Stumm, from the project director H.R. Wasmer, from our colleagues at the Lake Research Institute at Kastanienbaum, and from the Department of Hydrobiology. During the first year of the project, B. Eid and M. Rüttimann were part of our team. A. Paschke helped with some of the computer work, and members from the Institute for Environmental Physics at the University of Heidelberg made it possible to use the tritium/helium method for water age dating. We are grateful to all of them as well as to the still numerous individuals whom we did not mention.

\section{Boundary layers: the focus of mixing processes in lakes}

\section{a) Concept}

Internal transport processes in lakes are the result of a large number of different mechanisms which occur over a wide range of time and length scales of ever changing interaction. The trophic state of a lake is mostly controlled by those transport processes which occur in the vertical. They influence biological and chemical processes in that they provide nutrient transport from the lake bottom to the biologically active zone and oxygen transport into the deeper waters. Typically, vertical processes are generated by horizontal mechanisms. As a consequence, the energy contained in vertical processes is usually rather small and their effect can only be felt over a longer period of time. These long-term changes must be correlated to the dynamics of the horizontal processes.

Internal transport processes in lakes can only be explained in the framework of the system atmosphere-lake-sediment. Each of the three subsystems has its own dynamics. The interfaces between atmosphere-lake and sediment-lake can be characterized by the different ways in which the transfer processes take place.

Thermal and kinetic energy are both exchanged through the air-water interface. Since the atmospheric subsystem is controlled by a large number of cyclic and 
noncyclic time scales, transfer processes across the air-water interface only rarely reach steady state. The transfer across this interface is therefore characterized by individual events.

A totally different behaviour can be expected at the boundary between water and sediment. The size of the energy containing eddies close to the sediments is only a fraction of that in the atmospheric boundary layer. Thus the sediment-water transfer is generally less dynamic than that across the air-water interface. As will be seen later, there is, however, sometimes considerable activity in the water boundary layer above this interface.

As part of the atmospheric stimulation, an internal interface - the thermocline - is either formed, maintained or eroded. This interface is time varying on an annual scale, and responds to the stimulation on its own lake-specific time scale. For the trophic state of a lake this interface is of great importance, since it strongly alters the rate of vertical transport.

\section{b) Methods}

Mixing processes which influence the trophic state of Lake Baldegg have been analyzed in a long-term field program. During this study the dynamics of horizontal processes and the changes in vertical profiles were registered simultaneously.

Several instrument systems were installed in Lake Baldegg to study the dynamics of transfer processes across the interfaces. The atmospheric boundary layer was monitored from a buoy in the center of the lake. On this buoy a detailed temperature profile in the upper $1.5 \mathrm{~m}$ of the lake was also recorded. The behaviour of the thermocline was studied using thermistor chains in the appropriate depth range. Near the lake bottom horizontal currents were measured with a custom designed instrument (fig. 1, a).

It has become successful practice to study the long-term development of vertical processes using tracers. In Lake Baldegg several tracers were analyzed at the same

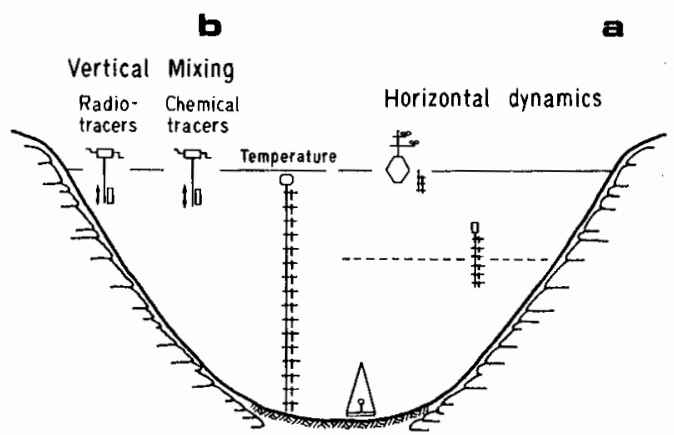

Figure 1. Measurements in Lake Baldegg for the study of mixing processes. a: Dynamic processes at three interfaces: lake surface, thermocline and lake bottom. The atmospheric input is registered on a meteorological buoy which is combined with a short thermistor chain for recording water temperatures near the surface. A thermistor chain at the thermocline depth tracks internal waves, and an underwater camera records currents at the deepest point of the lake. $b$ : The long-term effects of vertical mixing are followed by taking profiles of natural tracers and temperature. 
time. Since each of them is sensitive to a different time scale, it is possible to distinguish between several mechanisms which sometimes act simultaneously (fig. $1, b$ ).

\section{Natural tracers}

Natural tracers have been extensively used to study transport and mixing in the ocean [3]. Not all of the oceanographic techniques can be adapted to lacustrine systems. During the course of our project three types of tracers were employed:

1. Radon-222, a tracer for near-bottom transport in oceans [2] and lakes [14]: Its short half-life ( 3.3 days) renders it ideal to monitor mixing events through a 'memory filter' of about one week. The parent nuclide, radium-226 (half-life 1,620 yr) is concentrated in the sediments and provides a boundary source for the emanation of radon.

2. Total phosphorus and methane concentration in the anoxic hypolimnion of (eutrophic) lakes: Both species originate from the anaerobic degradation of organic matter in the sediments. They are nearly conservative in the water column (i.e. they have neither sinks nor sources) and thus monitor long-term vertical exchange processes in the hypolimnion.

3. Helium isotope ratio and tritium: The ratio of helium-3 to helium-4 in combination with the tritium concentration (a source of helium-3) permits to calculate the age of a water layer with respect to its exposure to the water surface, that is with respect to gas exchange with the atmosphere [34].

Frequently marine geochemists use the one-dimensional diffusion equation to describe the distribution of a tracer emanating from the sediments:

$$
\frac{\partial \mathrm{C}}{\partial \mathrm{t}}=\frac{\partial}{\partial \mathrm{h}}\left(\mathrm{K}_{\mathrm{z}} \frac{\partial \mathrm{C}}{\partial \mathrm{h}}\right)-\lambda \mathrm{C} .
$$

Boundary condition at bottom $(\mathrm{h}=0):\left.\frac{\partial \mathrm{C}}{\partial \mathrm{h}}\right|_{0}=-\mathrm{F} / \mathrm{K}_{\mathrm{z}}$.

$\mathbf{C}$ is concentration, $\mathbf{K}_{\mathbf{z}}$ vertical eddy diffusivity, $\lambda$ first order decay constant, $\mathbf{F}$ boundary flux per unit sediment area and time. The vertical coordinate $h$ is positive upwards and zero at the deepest point of the basin.

In lakes, however, the three-dimensional bottom topography can rarely be disregarded for the interpretation of vertical tracer distributions [14, 21]. Yet, the threedimensional diffusion-advection equation contains too many transport parameters to be determined from a single or even multiple tracer experiment. A significant simplification is achieved by the horizontally well mixed model which still retains some of the three-dimensional information of the lake basin:

$$
\frac{\partial \mathrm{C}}{\partial \mathrm{t}}=\frac{1}{\mathrm{~A}} \frac{\partial}{\partial \mathrm{h}}\left(\mathrm{AK}_{\mathrm{z}} \frac{\partial \mathrm{C}}{\partial \mathrm{h}}\right)+\frac{\mathrm{F}}{\mathrm{A}} \frac{\mathrm{dA}}{\mathrm{dh}}-\lambda \mathrm{C} .
$$

A is cross section of the lake decreasing with depth. 
Radon-222

A summary of all radon measurements carried out during this study is given in table 2. Unless otherwise mentioned vertical diffusivities were calculated with the horizontally well mixed diffusion model, equation (2). A more detailed approach was possible for Lake Baldegg, since excess radon was measured quasi-simultaneously at several stations and since analysis of the sediments for radium-226 allowed to calculate radon flux by an independent method. Details are explained by Imboden and Joller [16].

As an example, radon profiles from June 1978 are shown in figure 2. Horizontal mixing is obviously too slow to compensate for radioactive decay of radon entering the lake at the sediment-water interface and migrating laterally toward the center of the lake. The model curves in figure 2 are computed from a combined lateralvertical diffusion scheme. It turns out that radon activity close to the deepest part of

Table 2. Summary of radon measurements from various Swiss lakes. If not otherwise mentioned vertical diffusivity $K_{z}$ and radon flux $F$ are calculated by fitting the data to equation (2) with depth-independent $\mathrm{K}_{\mathrm{z}}\left(1 \mathrm{~m}^{2} \mathrm{~d}^{-1}=0.12 \mathrm{~cm}^{2} \mathrm{~s}^{-1}\right)$.

\begin{tabular}{|c|c|c|c|c|}
\hline Lake, date & $\begin{array}{l}\text { Zone above } \\
\text { bottom } \\
\text { (m) }\end{array}$ & $\begin{array}{l}K_{z} \\
\left(m^{2} d^{-1}\right)\end{array}$ & $\begin{array}{l}\text { Rn-flux from } \\
\text { sediment } \\
\left(\mathrm{dpm} \mathrm{m} \mathrm{m}^{-2} \mathrm{~d}^{-1}\right)\end{array}$ & Remarks \\
\hline \multicolumn{5}{|l|}{ Lake Baldegg } \\
\hline June to July 1977 & $0-8$ & $3-10$ & 390 & $\begin{array}{l}\text { From combined vertical-horizontal } \\
\text { diffusion model [14]; }\end{array}$ \\
\hline \multicolumn{5}{|l|}{ August to October } \\
\hline 1977 & $0-25$ & $1-10$ & 390 & $\begin{array}{l}\mathrm{K}_{\mathrm{x}} \text { decreases during the summer } \\
\text { from } 3,000 \text { to } 300 \mathrm{~m}^{2} \mathrm{~d}^{-1}\end{array}$ \\
\hline June 1978 & $0-25$ & $1-10$ & 390 & $\begin{array}{l}\mathrm{K}_{x} \text { between } 10^{3} \text { and } 10^{4} \mathrm{~m}^{2} \mathrm{~d}^{-1} \text { (see } \\
\text { fig. 2) }\end{array}$ \\
\hline \multicolumn{5}{|l|}{ Insite MELIMEX } \\
\hline \multicolumn{5}{|l|}{ limnocorrals May to } \\
\hline October 1977 & $0-2$ & $0.4-0.8$ & $100-200$ & $\begin{array}{l}\text { Since limnocorrals prevent lateral } \\
\text { transport, profiles are interpreted } \\
\text { with one-dimensional diffusion } \\
\text { model, equation (1); see [13]. }\end{array}$ \\
\hline $\begin{array}{l}\text { October } 1977 \\
\text { (sediments) }\end{array}$ & \multicolumn{2}{|c|}{$\begin{array}{l}\text { All depths (including } \\
\text { limnocorrals) }\end{array}$} & $390 \pm 50$ & $\begin{array}{l}\text { Flux calculated from escapable } \\
\text { radon content of lake } \\
\text { sediments }\end{array}$ \\
\hline \multicolumn{5}{|c|}{ Lake Lucerne (Urnersee) } \\
\hline 7 August 1979 & $0-15$ & $0.1-0.5$ & 1,000 & \\
\hline 17 October 1979 & $0-15$ & 10 & 1,000 & $\begin{array}{l}\text { Samples were taken shortly after } \\
\text { flood in main inlet Reuss. Water up } \\
\text { to } 5 \mathrm{~m} \text { from the sediment was turbid }\end{array}$ \\
\hline 29 October 1979 & $0-20$ & 1 & 500 & No turbid water found in the lake \\
\hline \multicolumn{5}{|l|}{ Lake Brienz } \\
\hline 29 September 1979 & $0-10$ & 1.1 & $2,500-3,000$ & \\
\hline 4 December 1979 & $0-10$ & 0.6 & 1,500 & \\
\hline \multicolumn{5}{|l|}{ Lake Zïrich } \\
\hline Sediment cores & & & $350 \pm 100$ & $\begin{array}{l}\text { No coherent profile of excess radon } \\
\text { found in water column }\end{array}$ \\
\hline
\end{tabular}




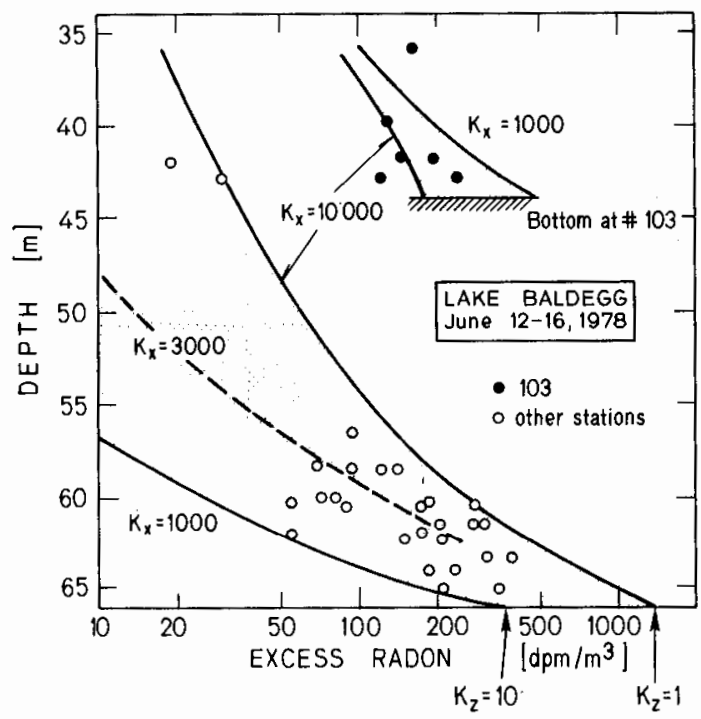

Figure 2. Excess radon in Lake Baldegg from five stations. Station 103 is close to station 201 (see fig. 6); all other profiles were taken at stations in the central part of the lake (water depth between 62 and $66 \mathrm{~m}$ ). Radon flux from the sediments is $390 \mathrm{dpm} \mathrm{m}^{2} \mathrm{~d}^{-1}$. Model curves are from combined horizontal $\left(\mathrm{K}_{\mathrm{x}}\right)$ and vertical $\left(\mathrm{K}_{2}\right)$ diffusion model (from [16]).

the lake is predominantly determined by the size of the vertical diffusivity $K_{z}$, whereas in the higher layers the activities reflect the size of lateral diffusivity $\mathbf{K}_{\mathrm{x}}$. Obviously, there is no unique interpretation of the profiles, but the range of possible $\left(\mathrm{K}_{\mathrm{z}}, \mathrm{K}_{\mathrm{x}}\right)$ values is at least narrowed to one order of magnitude.

An interesting feature was found in the southern basin of Lake Lucerne (Urnersee, see table 2): Radon samples, taken one day after flood conditions in the major inlet to the basin (River Reuss), indicate high vertical diffusivity. Turbid water was found in those samples which were taken $5 \mathrm{~m}$ and less above the lake bottom. Twelve days later, eddy diffusivity was low again, the water free of turbidity. It seems that (at least part of) the inlet loaded with particles followed the bottom of the lake. Apparently, the radon profiles were not produced by large vertical diffusion but by lateral advective transport.

The results from these and other data can be summarized as follows:

1. The classic exponential radon profiles are rare; many profiles have a transient and irregular shape.

A direct demonstration of the transient character of radon profiles has been given by Nyffeler et al. [29] for Lake Biel.

2. The occurrence of measurable excess radon is often limited to the water layer extending only a few meters from the sediments. This restricts the exploitability of radon-222 as a mixing indicator.

3. Simultaneous action of lateral and vertical transport complicates the evaluation of $\mathrm{K}_{\mathrm{z}}$ values. Therefore, radon flux intensities should be directly determined from sediment analysis and not by fitting measured radon activities to model curves. 
Conservative tracers: methane and total phosphorus

Methane and phosphorus were measured in Lake Baldegg by Joller [19] between 1978 and 1980. From August to November 1978, the period chosen as an example, methane concentrations increased linearly with time below $20 \mathrm{~m}$ (fig.3). The rate of change, $\partial \mathrm{CH}_{4} / \partial \mathrm{t}$, was growing with depth (fig.4). Since methane oxidation in the

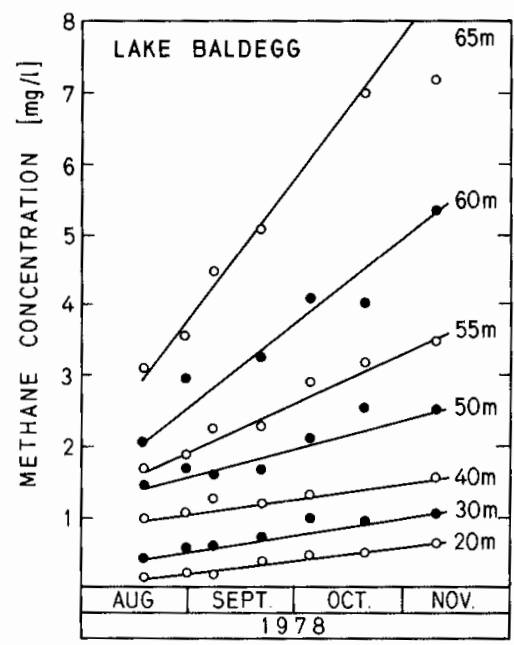

Figure 3. Methane concentration in Lake Baldegg at various depths for period 17 August to 7 November 1978 (from [19].

TEMPORAL INCREASE OF METHANE, $\frac{\partial\left[\mathrm{CH}_{4}\right]}{\partial t}$

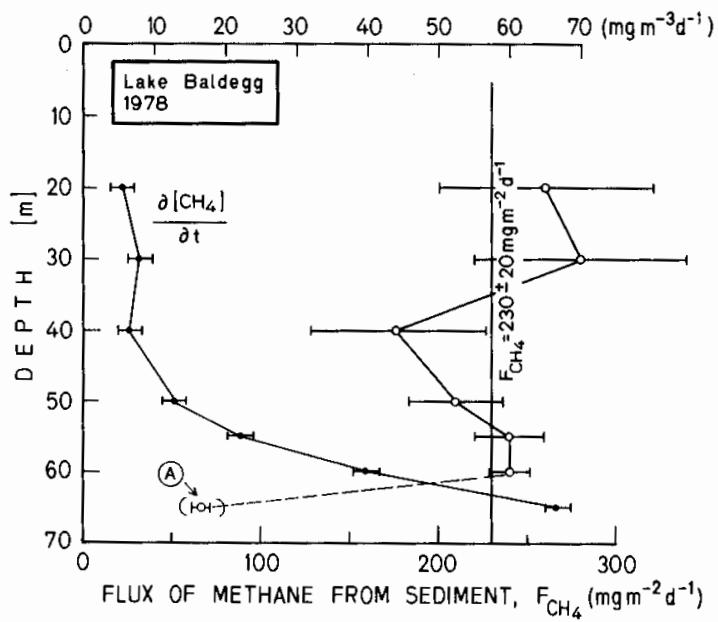

Figure 4. Depth-dependent temporal increase of methane concentration in Lake Baldegg for period August to November 1978 calculated from data in figure 3 and equation (3). Flux at $65 \mathrm{~m}$ (point A) is underestimated by the model because vertical diffusional transport is predominant due to high concentration gradients. 
anoxic zone of the lake is quite slow, methane in Lake Baldegg is quasi-conservative at depths larger than $20 \mathrm{~m}$ during most of the year.

Neglecting vertical diffusion, equation (2) can be simplified to

$$
\frac{\partial\left[\mathrm{CH}_{4}\right]}{\partial \mathrm{t}}=\mathrm{F}_{\mathrm{CH}_{4}}(\mathrm{~h}) \cdot \mathrm{a}(\mathrm{h}), \quad \mathrm{a}(\mathrm{h})=\frac{1}{\mathrm{~A}} \frac{\mathrm{dA}}{\mathrm{dh}} .
$$

The topographic function $a(h)$ is sediment surface per volume increment, $d A / d V$; for Lake Baldegg $A(h)$ is linearly increasing with $h$ (fig. 2). Using equation (3) the methane flux from the sediments is $(230 \pm 20) \mathrm{mg} \mathrm{m}^{-2} \mathrm{~d}^{-1}$ and constant with depth (fig. 4).

The linear increase of methane concentration with time in the hypolimnion and the uniform size of the flux calculated from the simple model (eq.3) indicate that the vertical distribution of a conservative compound diffusing from the sediments is not patterned by vertical mixing but by the lake topography, or more specifically, by the in situ ratio between sediment surface and water volume. A compound with similar properties should thus behave alike. Indeed, increase of total phosphorus concentration relative to the value in spring, $\Delta \mathrm{P}_{\mathrm{to}}$, is proportional to methane concentration. This indicates that both species have the same source (sediment surface) and are both quasi-conservative in the water column. The ratio, $\Delta \mathrm{P}_{\text {tot }}:\left[\mathrm{CH}_{4}\right]$, must be equal to the flux ratio, $\mathrm{F}_{\mathrm{P}}: \mathrm{F}_{\mathrm{CH}_{4}}$. As shown in table 3, the calculated P-flux from the sediments represents an important source to Lake Baldegg.

Joller [19] has examined other chemical species which are related to redox processes at the sediment-water interface (ammonium, iron, manganese, sulfide). He found considerable agreement with the mixing pattern established for methane and phosphorus. Also, within the anoxic zone of the water column where these tracers are conservative or only moderately reactive, they seem to be quite insensitive to transient mixing structures.

Table 3. Methane and phosphorus fluxes from sediments of Lake Baldegg. $\mathrm{F}_{\mathrm{CH}_{4}}$ is calculated from equation (3) (fig. 4), the flux ratio, $\mathrm{F}_{\mathrm{P}}: \mathrm{F}_{\mathrm{CH}_{4}}$, is calculated from the linear correlation between methane and phosphorus concentration in the water column.

\begin{tabular}{|c|c|c|c|c|c|}
\hline & $\begin{array}{l}\left.\mathrm{F}_{\mathrm{P}}: \mathrm{F}_{\mathrm{CH}_{4}}{ }^{\prime}\right) \\
\left(\mathrm{gP} / \mathrm{gCH}_{4}\right)\end{array}$ & $\begin{array}{l}\mathrm{F}_{\mathrm{CH}_{4}} \\
\left(\mathrm{mgm}^{-2} \mathrm{~d}^{-1}\right)\end{array}$ & $\begin{array}{l}F_{P} \\
\left(\mathrm{mgm}^{2} \mathrm{~d}^{-1}\right)\end{array}$ & $\begin{array}{l}\text { Total } \mathbf{P} \text { input } \\
\text { Internal })^{2} \\
\left(\mathrm{kgd}^{-1}\right)\end{array}$ & External $^{3}$ ) \\
\hline $\begin{array}{l}\text { June } 1978 \text {, from [16] } \\
\text { August to Novem ber }\end{array}$ & $(0.091)$ & $230 \pm 20$ & $(21 \pm 2)$ & $(80 \pm 8)$ & 36 \\
\hline 1978, from $[19]$ & $\left.0.050^{4}\right)$ & $260 \pm 60$ & $13 \pm 3$ & $50 \pm 11$ & \\
\hline
\end{tabular}

1) If all methane were formed by acetat fermentation and the plankton had Redfield composition (molar ratio $\mathrm{P}: \mathrm{C}=1: 106)$, the expected flux ratio would be $0.037 \mathrm{gP} / \mathrm{gCH}_{4}$.

2) P-flux assumed to occur from sediment area below $20 \mathrm{~m}\left(3.8 \times 10^{6} \mathrm{~m}^{2}\right)$.

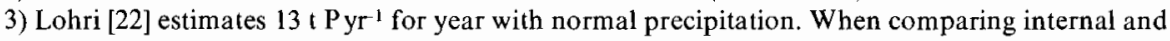
external fluxes note that the former does only occur during 6-8 months.

4) Value calculated from ratio, $\triangle \mathrm{PO}_{4}:\left[\mathrm{CH}_{4}\right]$, is more realistic than value for June when only $P_{\text {tot }}$ was determined. 


\section{Helium isotopic ratio and tritium}

In collaboration with the Institute for Environmental Physics at the University of Heidelberg, we have measured tritium activity and isotopic helium ratio, ${ }^{3} \mathrm{He}:{ }^{4} \mathrm{He}$, in Lake Baldegg during one year. Based on data from the first period of the investigation Imboden et al. [17] have shown that:

1. During the early period of thermocline erosion (October to December 1979) vertical mixing occurs quasi-diffusional, though the discrepancy between diffusivities calculated from helium and temperature, respectively, could originate from nonlocal mixing processes [12].

2. During winter (December 1979 to February 1980) renewal of the water below $40 \mathrm{~m}$ was about $50 \%$; complete homogeneity was prohibited by a chemically induced density gradient [19].

3. Gas exchange for ${ }^{3} \mathrm{He}$ during winter $1979 / 80$ averaged to about $1.3 \mathrm{~m} / \mathrm{d}$; depending on the appropriate model of gas exchange this corresponds to a value between 0.7 and $1.0 \mathrm{~m} / \mathrm{d}$ for oxygen.

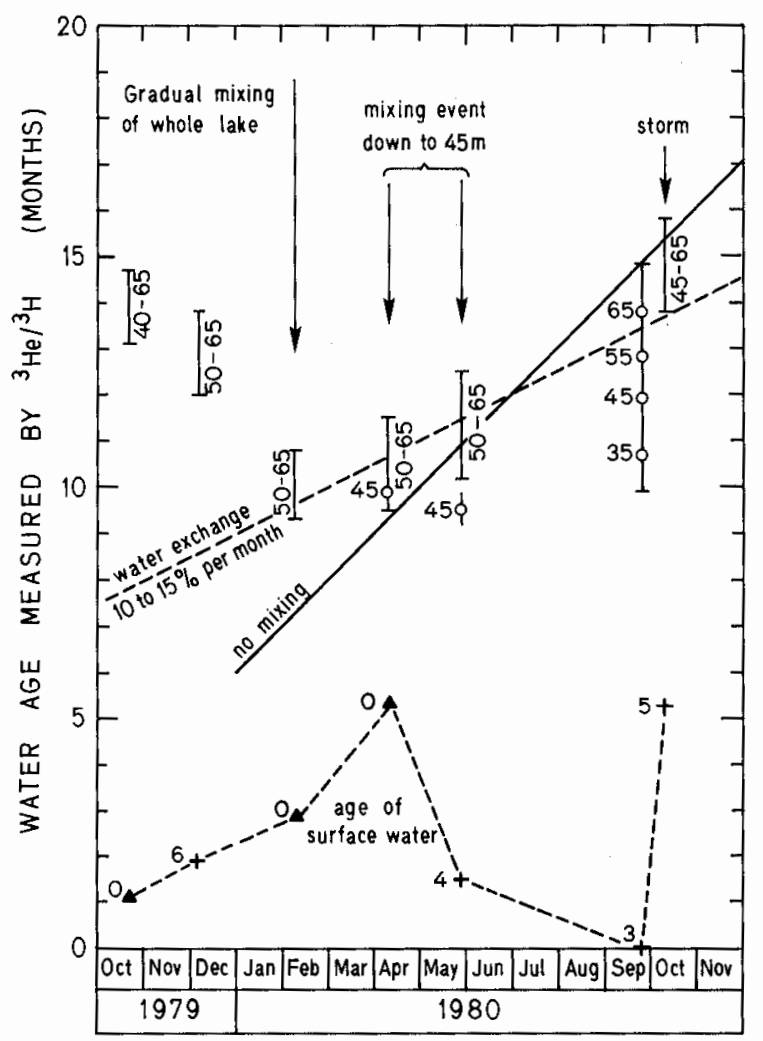

Figure 5. Water age in Lake Baldegg calculated by tritium and isotopic helium ratio. Numbers refer to depth (meters). The 'no-mixing' line and the line for water exchange between 10 and $15 \%$ are only fixed by their slopes but drawn arbitrarily, otherwise. Helium and tritium samples were measured at the Institute for Environmental Physics, University of Heidelberg. 
Measurement of the other helium samples was delayed until fall 1982 due to technical problems at the laboratory in Heidelberg. In spite of the long storage time and of loss of a few samples, it is still possible to follow the fate of the hypolimnic water during summer 1980 (fig. 5). Having reached a minimum in February, age of the water below $50 \mathrm{~m}$ grew more slowly than indicated by the no-mixing-line. This means that deep hypolimnic water was replaced (probably by water from the upper hypolimnion) at a rate of 10 to $15 \%$ per month. Between April and May, the water age at $45 \mathrm{~m}$ points to a mixing event which was felt down to this depth. Unfortunately, our meteorological recording system on the lake (chapter 4) failed between 9 April and 14 May 1980. However, strong winds and significant cooling started already on 1 April. The temporary erosion of the still weak thermocline caused by the weather change is reflected by the large surface age (about 5 months). A similar effect is seen on 9 October: The samples were taken during a storm (winds about $12 \mathrm{~m} / \mathrm{s}$ ) while air temperature was about $10^{\circ} \mathrm{C}$ below water temperature and thus mixing was large. The sudden increase of water age below $45 \mathrm{~m}$ may result from a temporary dislocation of the old water by wind forces and cooling.

The results from Lake Baldegg demonstrate that helium measurements are an ideal complement to the chemical tracers, especially during the winter when most chemical gradients disappear but mixing still may be incomplete.

\section{Distribution of heat in Lake Baldegg}

\section{a) Instrumentation}

In the center of Lake Baldegg a buoy measured meteorological variables and lake temperatures between depths of $0.5 \mathrm{~m}$ and $1.5 \mathrm{~m}$ (station 102, fig. 6). The temperature distribution in the lake was recorded at three buoy stations (station 201, 202 and 203 in fig. 6) with thermistor chains between $2.50 \mathrm{~m}$ and $44.50 \mathrm{~m}$. The location of the mooring stations and the depth of the individual thermistor chains were maintained from October 1979 to December 1980. A more detailed description of the measurement systems (built by Aanderaa) and plots and tables of the measured data are presented in [4].

\section{b) Wind data}

Lake Baldegg is situated in a sheltered location, and extended periods of high winds are very rare. Figure 7 shows the wind speed histogram and the wind rose for the period June 1980 to November 1981 calculated from hourly means. Wind speeds above $3.5 \mathrm{~m} / \mathrm{s}$ account for $12 \%$ of the total time. Speeds above $7.5 \mathrm{~m} / \mathrm{s}$ almost only occur during thunderstorms and frontal passages. As can be seen from the wind rose, wind directions are oriented along the lake axis. The dominant features are: 1. Winds below $1.5 \mathrm{~m} / \mathrm{s}$ blow mainly from the southeast. 2 . Winds between $1.5 \mathrm{~m} / \mathrm{s}$ and $5.5 \mathrm{~m} / \mathrm{s}$ are predominantly from the northwest. 3. Higher winds associated with fronts and thunderstorms come mostly from the west (across the lake) and the northwest. 


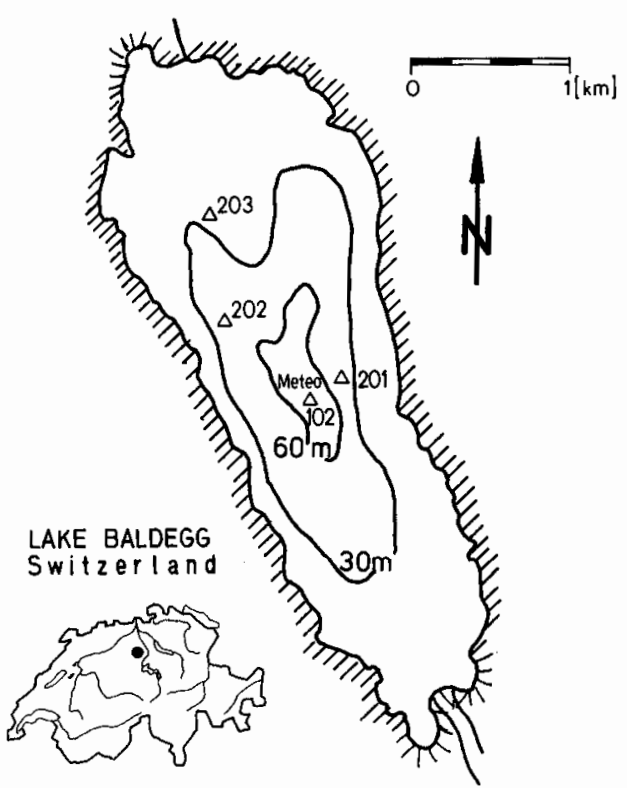

Figure 6. Map of Lake Baldegg. Measuring stations are indicated by numbers. Station 102: Meteorological buoy and sampling station for all chemical tracers (radon, helium-3, tritium, methane, phosphorus). Stations 201, 202, 203: mooring stations for thermistor chains. Inset: Location of Lake Baldegg in Switzerland.

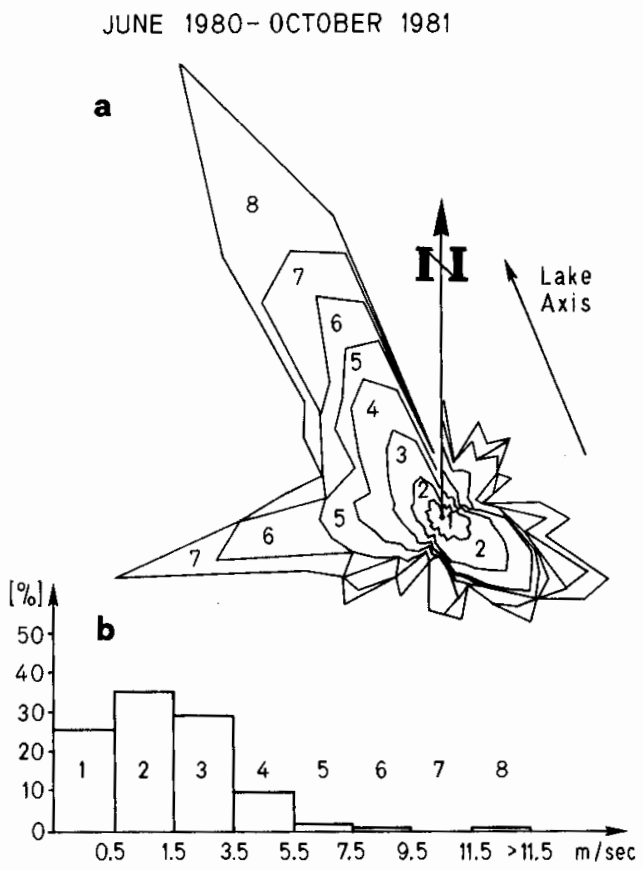

Figure 7. Windrose (part a) and wind speed histogram (part b), calculated from hourly mean values. Accumulation period: June 1980 to October 1981. Total number of samples: 11,192. 


\section{c) Surface water temperatures}

Because of the low wind input, strong diurnal temperature gradients in the upper lake boundary layer are frequently observed. For the stratification period from April to August 1981, the maximum differences between the hourly mean water temperatures in $0.05 \mathrm{~m}$ and $1.5 \mathrm{~m}$ depth have been calculated and summed up separately for day- and nighttime. Whenever the difference was between 0 and $0.2 \mathrm{~K}$, the hourly mean winds were calculated. For comparison, separate wind histograms for the total day and night periods were also calculated. The results are presented in figure 8 and can be summarized as follows:

1. A homogeneous surface layer exists only during about $25 \%$ of the daytime period. This mixing is achieved by winds which are typically above $1.5 \mathrm{~m} / \mathrm{s}$. The total wind histogram for the daytime indicates that lower wind speeds occur, but they are not strong enough to produce mixing. On the other hand, it becomes
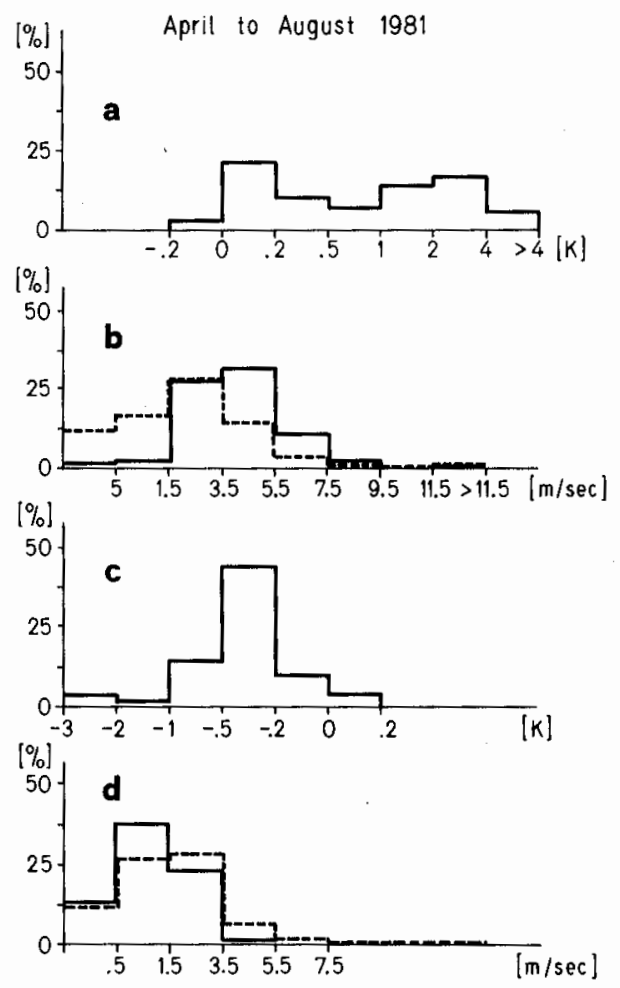

Figure 8. Meteorological buoy on Lake Baldegg. Hourly mean values for the period April to September 1981:

a: Histogram of maximum water temperature difference: $0.05 \mathrm{~m}$ to $1.5 \mathrm{~m}$ (daytime observations). b: Histogram of wind velocities at $8 \mathrm{~m}$ (daytime observations). Solid line: for all time periods during which the maximum temperature difference was 0 to $0.2 \mathrm{~K}$. Dashed line: for all winds.

c: same as a for nighttime observations. $\mathrm{d}$ : same as b for nighttime observations. 
obvious that not all winds between $1.5 \mathrm{~m} / \mathrm{s}$ and $3.5 \mathrm{~m} / \mathrm{s}$ can achieve complete mixing either. On the remaining days, stratification is well developed in the upper $1.5 \mathrm{~m}$ of the lake. Temperature differences can exceed $4 \mathrm{~K}$.

2. Stratification is eroded at night. Most of the time a slightly unstable or almost homogeneous layer is formed partially because of heat loss to the atmosphere and partially because of wind (fig. $8, \mathrm{c}$ and d). Since both processes work in the same direction, lower winds can produce mixing at night. Whenever positive gradients remain at night, they tend to be small.

Our data show that on Lake Baldegg a wind-mixed epilimnion is not a common feature. Following the classification of Spigel and Imberger [33], this lake would belong to regime 3 described as buoyancy controlled with occasional wind induced mixing.

\section{d) Mean temperature distribution}

Mean temperatures at depths below $2.5 \mathrm{~m}$ were calculated for half-month periods for all stations. As an example, the temperature distribution below $20 \mathrm{~m}$ at station 202 is presented in figure 9. Stratification in this depth range is slight but stable. Between April and November 1980, the vertical temperature gradient changes little with time, while temperatures rise by about $0.1 \mathrm{~K}$ in the hypolimnion below $28 \mathrm{~m}$.

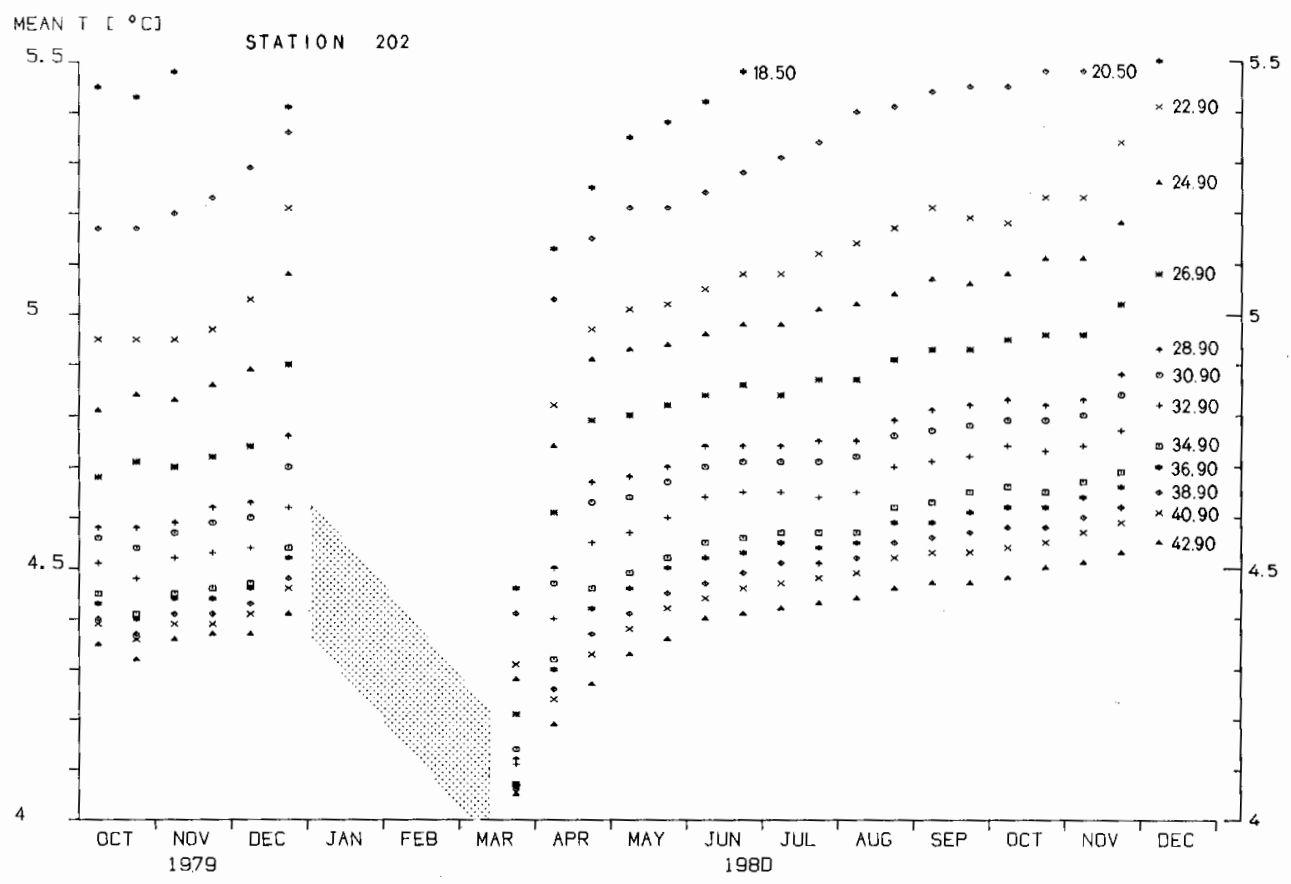

Figure 9. Mean temperature distribution below $18.5 \mathrm{~m}$ in Lake Baldegg at station 202 calculated for halfmonth periods from thermistor chain records (sampling interval $20 \mathrm{~min}$ ). For each symbol the water depth $(m)$ is indicated. 
This is significantly less than reported by $\mathrm{Li}$ [20] for the same depth range in Lake Zürich, reflecting the smaller wind induced mixing in Lake Baldegg.

\section{e) Heat budget}

From the mean temperatures, the heat storage in the upper $42.5 \mathrm{~m}$ of the lake (taking $0{ }^{\circ} \mathrm{C}$ as a baseline) and heat flux in the lake over half-month periods was calculated (fig, 10). The heat flux shows the highest value in April, followed by a period of almost constant heat flux until June. In late June and July, cool weather reduces the heat flux temporarily.

During the time of heat export from the lake, the values of the heat flux show significant scatter. This indicates that mixing during this period of decreasing stratification is affected more strongly by individual events. Note that the time period shown in figure 10 extends over more than a full year. With respect to heat, the lake is approximately in cyclic steady state.

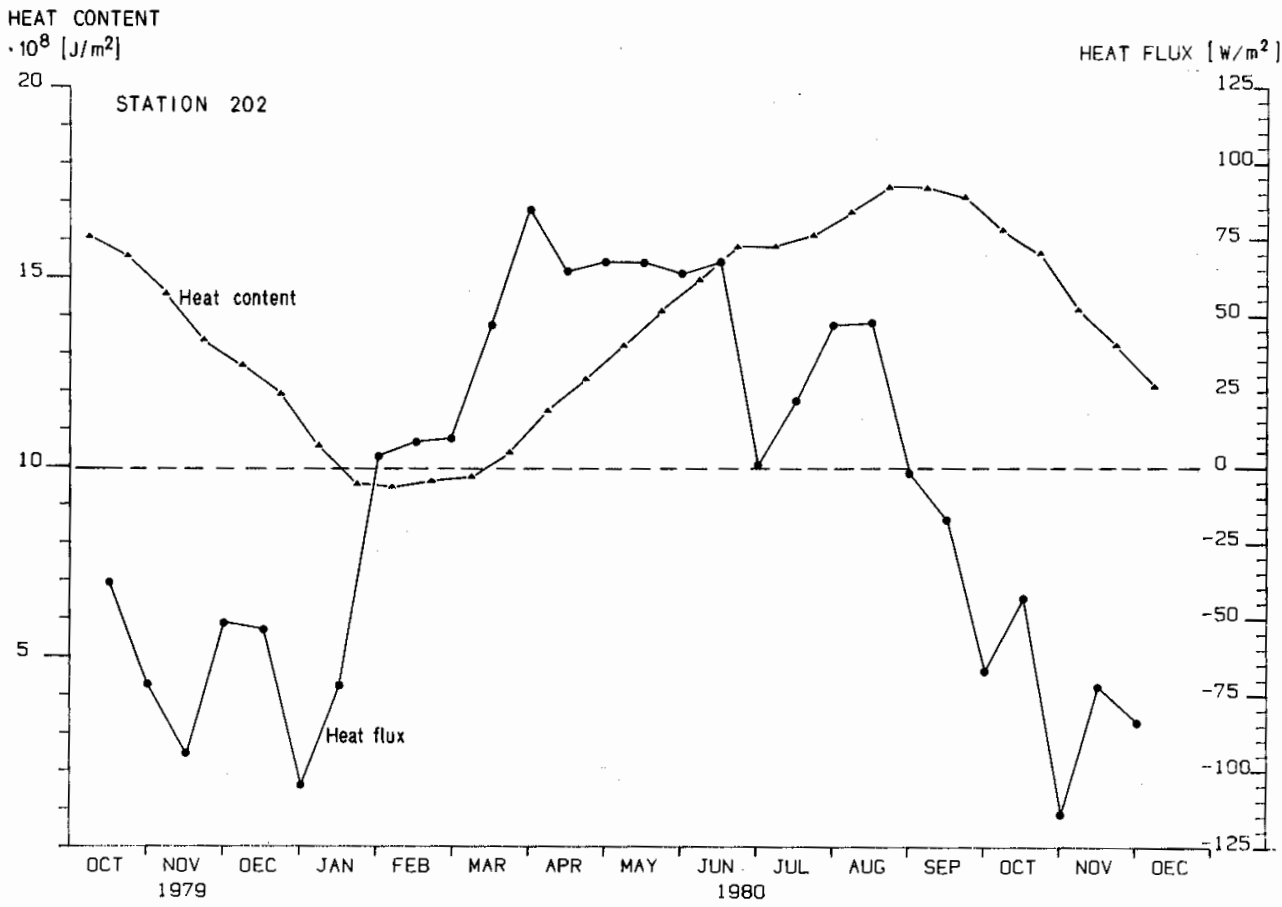

Figure 10. Heat content (relative to $0^{\circ} \mathrm{C}$ ) and heat flux at station 202, calculated for the upper $42.5 \mathrm{~m}$ of the lake.

\section{f) Vertical diffusion coefficients}

The mean temperature data are used to estimate vertical diffusivity, varying in space and time. Applying the flux gradient method with depth dependent lake area 
$[19,31]$, the values of the vertical thermal diffusion coefficient $\mathrm{K}_{\mathrm{z}}$ can be calculated as:

$$
K_{z}=\frac{-\int_{z}^{z_{\max }} A(\partial T / \partial t) d z}{A(\partial T / \partial z)}
$$

T is temperature $\left({ }^{\circ} \mathrm{C}\right)$ at depth $\mathrm{z}(\mathrm{m})$; $\mathrm{A}$ is area of the basin $\left(\mathrm{m}^{2}\right)$ at depth $\mathrm{z}$ and $\mathrm{t}$ is time (s).

It is standard procedure to evaluate this equation from individual temperature profiles commonly taken at intervais of several days. Due to internal waves and the dynamic response of the lake to external forces, the resultant diffusion coefficients quite often have a rather low reliability. In our study, mean temperatures and linear trend $\left(\partial^{\prime} \mathrm{T} / \partial \mathrm{t}\right)$ were calculated from more than 1,000 single temperature recordings. The results are presented in figure 11 for the depths $6.5 \mathrm{~m}$ to $42.9 \mathrm{~m}$.
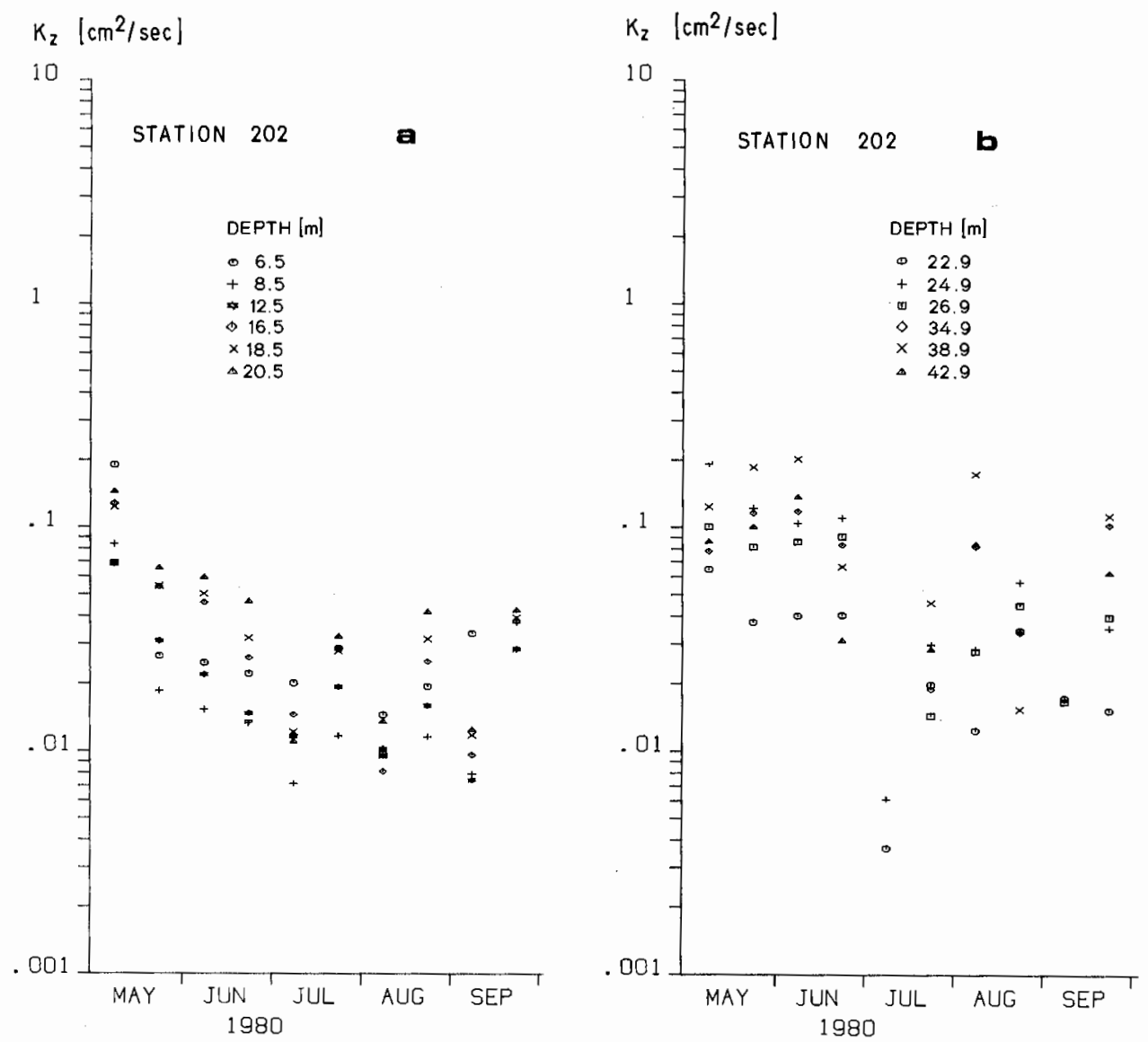

Figure 11. Vertical eddy-diffusion coefficients $K_{2}$ at station 202. Depth range: $6.5-20.5 \mathrm{~m}$ (part a) and $24.9-42.9 \mathrm{~m}$ (part b). 
Only coefficients from May to September are included. During the remainder of the year, large scale convective mixing is the dominant mechanism which cannot be described by the flux gradient method. The epilimnion above $6.5 \mathrm{~m}$ has been omitted, since mixing in this part is not achieved by diffusive processes either.

At the onset of stratification, diffusivities are similar throughout the water column. In the region of the thermocline, vertical diffusion coefficients drop between May and September (fig. 1la) with progressing stratification. In the hypolimnion they remain more constant with time. In the mean, values are slightly higher in the hypolimnion than in the thermocline. Values in the same range of magnitude have also been observed by Li [20] for Lake Zürich, by Jassby and Powell [18] for Castle Lake and by Wirz [38] for Lake Biel.

In order to compare the eddy-diffusion coefficients obtained from temperature with the rate of mixing found from the helium-3 measurements (chapter 3), one can assume that the volume of the lowest part of the lake divided by the appropriate surface area expresses a mixing length. The rate of exchange multiplied by the square of the mixing length is then a qualitative estimate for the eddy-diffusion coefficient. Assuming a mixing length of $10 \mathrm{~m}$ for the lowest part of the lake and taking a mixing rate of 0.10 to 0.15 month $^{-1}$, one arrives at a value for $\mathrm{K}_{\mathrm{z}}$ in the order $0.04-0.06 \mathrm{~cm}^{2} / \mathrm{s}$. This is within the range of $\mathrm{K}_{\mathrm{z}}$ values obtained from our temperature measurements.

Vertical eddy diffusivities, calculated from radon-222 for the deepest $10-20 \mathrm{~m}$ of Lake Baldegg, are between 0.1 and $1 \mathrm{~cm}^{2} / \mathrm{s}$ (table 2). These values are significantly higher than those computed from water temperature. With respect to water exchange traced by helium, the radon data would indicate a larger mixing length.

Discrepancies between mixing rates traced by heat and chemical tracers have been found before [17]; they may indicate higher mixing intensity along the bottom of the lake (for instance driven by bottom currents, see chapter 6 ), or originate from the sensitivity of the tracers to different time scales and thus to different mixing mechanisms [13].

\section{g) Diffusion coefficients versus Brunt-Väisälä frequency}

In a theoretical analysis Welander [37] has shown that the vertical diffusion coefficient $\mathrm{K}_{\mathrm{z}}$ can be related to the square of the Brunt-Väisälä frequency $\mathrm{N}^{2}$, a measure for the intensity of stratification. He discusses two extremes. In the first case, turbulence is generated by a cascading process and the relation can be written as:

$$
\mathrm{K}_{\mathrm{z}}=\operatorname{const}^{*}\left(1 / \mathrm{N}^{2}\right) \text {. }
$$

In the second case, turbulence is generated by instability of local shear:

$$
\mathrm{K}_{\mathrm{z}}=\text { const } *\left(1 / \sqrt{\mathrm{N}^{2}}\right) \text {. }
$$

In these equations $\mathrm{K}_{2}$ represents the turbulent part of the vertical diffusion from which the molecular value has been subtracted. $K_{z}$ is plotted versus $\mathrm{N}^{2}$ (fig. 12) for several periods during stratification. The variation in the shape of the curves indicates that at different times different mechanisms dominate the mixing pattern. It should be noted that change in the profiles is mainly due to variation in the $\mathrm{K}_{\mathrm{z}}$ 


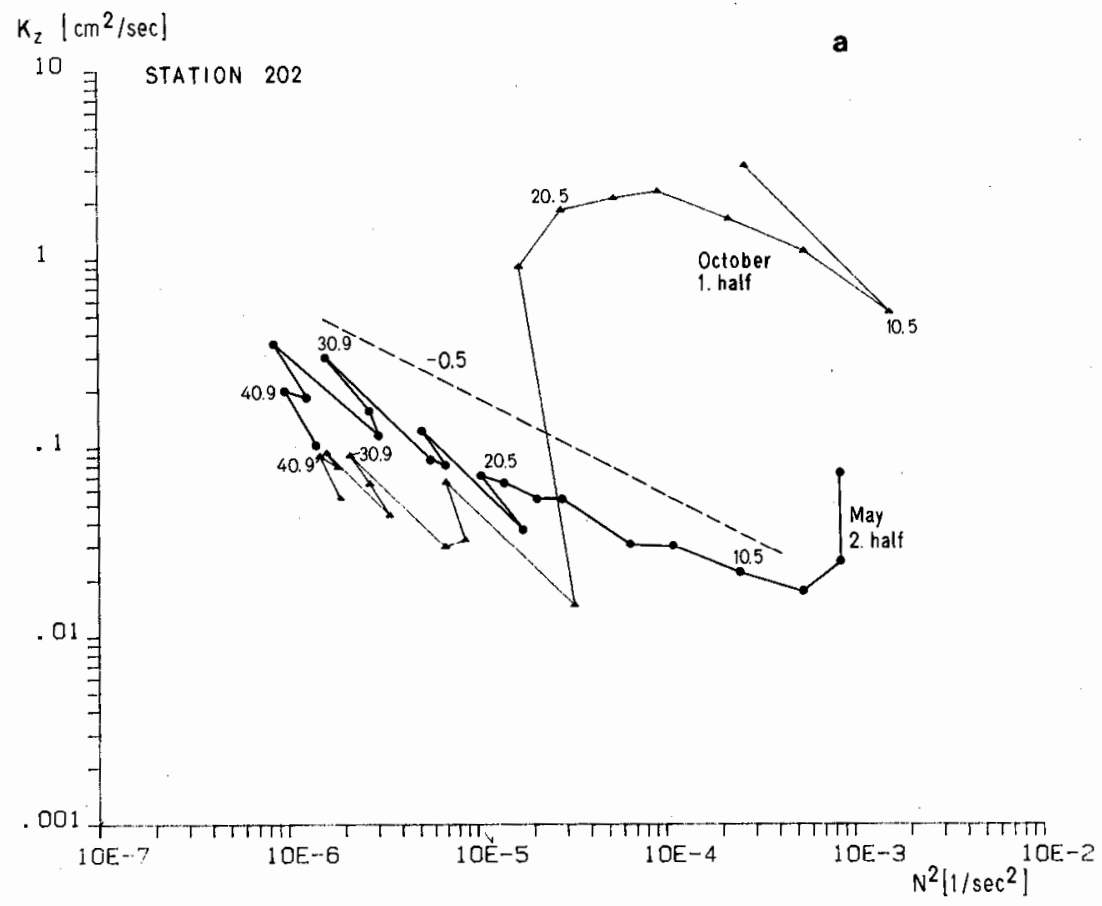

$\mathrm{K}_{2}\left|\mathrm{~cm}^{2} / \mathrm{sec}\right|$

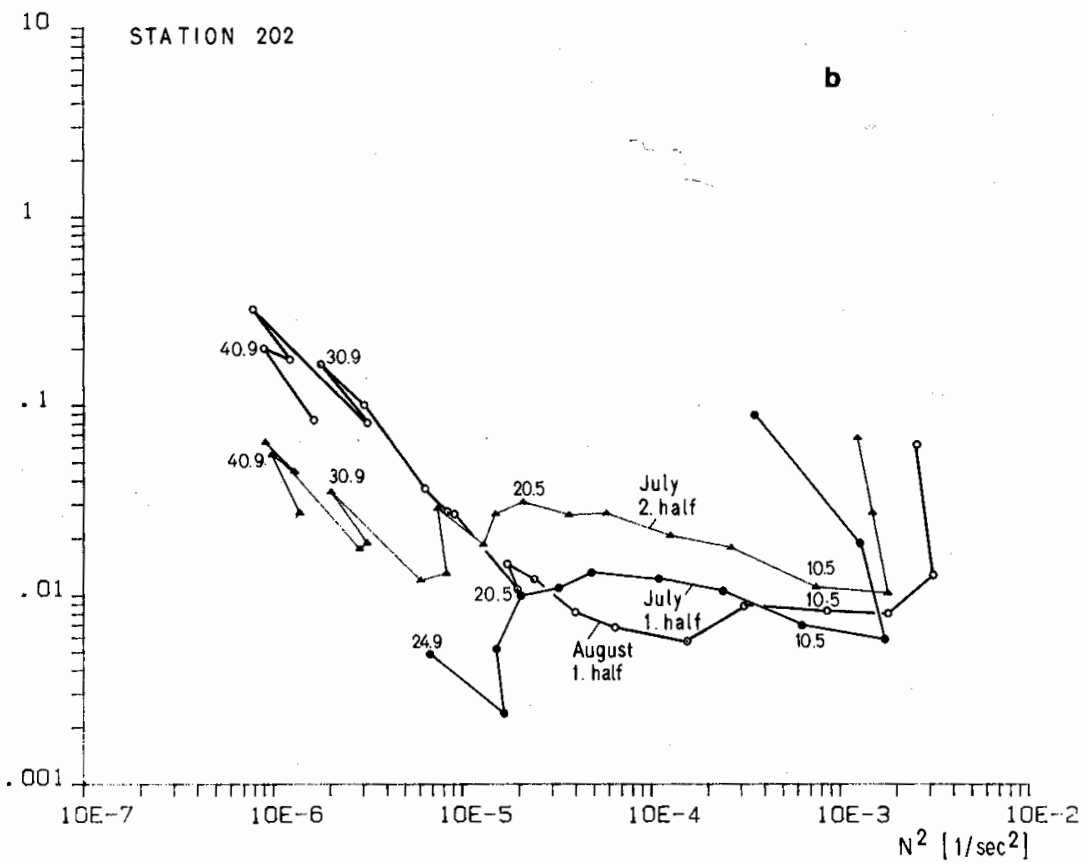

Figure 12. Vertical eddy-diffusion coefficients $K_{z}$ versus the square of the Brunt-Väisälä frequency $N^{2}$. Numbers indicate water depth (meters). 
values. The stratification in each depth range, expressed by the Brunt-Väisälä frequency $\mathrm{N}^{2}$, changes much less in comparison.

The curve for late May (fig. 12a) represents a typical profile during increasing stratification. There exists a depth range $(10.5 \mathrm{~m}$ to $20.9 \mathrm{~m})$ in which the slope of the curve is close to -0.4 . Following Welander's theory, shear induced turbulence would govern mixing in this depth range below the thermocline. Comparable profiles have also been observed by Jassby and Powell [18] during stratification for a similar depth range. Below $22 \mathrm{~m}$ the slope of the curve is slightly above -0.5 .

Between 15 June and 3 July, due to a cool weather period with low radiation and winds frequently above $3 \mathrm{~m} / \mathrm{s}$, the lake surface temperature continuously decreased from above $20^{\circ} \mathrm{C}$ to below $17^{\circ} \mathrm{C}$. The temperature difference between air and water surface remained negative at all times, the heat flux into the lake decreased (fig. 10) and the mixing pattern was altered. The shape of the curve has changed from May to early July (fig. 12b). Therefore, it can be assumed that mixing is caused by processes other than vertical diffusion. Later in July, the weather improved and the lake gained heat again. $\mathrm{K}_{\mathrm{z}}$ values increase, but the curve does not follows any of the predicted slopes (fig. 12b).

In the first half of August, the shape of the curve is comparable to the one in May, but the $\mathrm{K}_{\mathrm{z}}$ values are lower now (fig. 12b). A similar seasonal behaviour was also observed by $\mathrm{Li}[20]$ in Lake Zürich. The decrease in magnitude in Lake Baldegg is comparable to that in Lake Zürich over the same period of time. The heat flux calculation indicates stagnation from late July to early August. While the slope of the curve between $10 \mathrm{~m}$ and $20 \mathrm{~m}$ no longer follows Welander's theory, the one between $24 \mathrm{~m}$ and $40 \mathrm{~m}$ comes close to -1 .

A fall situation is shown in figure $12 \mathrm{a}$. In the curve for early October, $\mathrm{K}_{\mathrm{z}}$ values in the upper $22 \mathrm{~m}$ have drastically increased, while the deeper waters are still unaffected. Large scale convective turbulence and stronger wind induced turbulence start to influence the mixing at this time of the year. Therefore in the upper $20 \mathrm{~m}$, they cause mixing by nondiffusive processes. The shape of the curve in the upper $20 \mathrm{~m}$ is comparable to that in early July.

The analysis of the temperature measurements reveals that during most of the time of stratification, vertical mixing in the hypolimnion can be described as a diffusive process. We found a good correlation with the results from our tracer measurements. During this time, turbulence in the upper range of the hypolimnion is generated by local shear. In the lower range, where temperature gradients fall below $0.08 \mathrm{~K} / \mathrm{m}$, cascading turbulence seems to dominate.

There exist, however, periods during stratification in which mixing is achieved by other mechanisms. These periods have been identified by strong changes in the atmospheric energy input conditions. Although vertical diffusion coefficients can formally be computed for such periods, they are meaningless for the calculation of transport of water and solutes.

\section{Internal waves}

Surface seiches and internal waves were among the first motions to be observed in a lake $[6,36]$. Since they contribute to mixing, their analysis was included in our 
investigation of Lake Baldegg. The three thermistor chain stations (fig. 6) were positioned such that station 203 would be most sensitive to the uninodal basin-wide standing wave, station 201 to the binodal wave and station 202 to higher harmonics. This mooring configuration also allows the study of rotating waves should they exist. This aspect will not be dealt with in this paper.

\section{a) General observations}

The temperature records reveal that as soon as stratification sets in, internal waves can be found at the thermocline depth in Lake Baldegg. Once excited, they usually persist for more than a week with only slight damping. Typically a wave pattern is destroyed by a new wind induced setup, rather than by decay. In contrast to previous observations [25], the harmonics do not show significant damping. This pattern continues late into fall. Even during periods of weak stratification and thermocline erosion in November and December, internal waves still persist between storm events. The period of oscillation increases with the deepening of the thermocline during the cooling period.

Isotherms from two stations during October 1979 and June 1980 show very different patterns (fig. 13). During the period of decreasing stratification in October, the uninodal wave is dominant at station 203 and the binodal wave can be clearly traced at station 201. The lake first responds with a uninodal wave. Binodal and higher harmonics are excited afterwards (fig. 13a).

During the period of increasing stratification in June, the basic oscillations are obscured by waves of higher frequencies. The amplitudes of the basic waves are usually higher in June than in October. An explanation for these differences can be found from the mean temperature profiles. In October, the thermocline is rather sharp with an epilimnion of almost homogeneous temperature. This comes close to the situation of a two-layer lake. In June, the temperature between $6.5 \mathrm{~m}$ and $18.5 \mathrm{~m}$ shows a continuous gradient. This represents the case of a multilayer lake. Our data show that in such a system higher frequency oscillations are more easily excited and waves can have higher amplitudes.

\section{b) Spectral analysis}

A set from October 1979 was chosen to demonstrate the generally valid findings. From the data records obtained, records of isotherm depth were calculated. Isotherms for $11^{\circ} \mathrm{C}$ and $8{ }^{\circ} \mathrm{C}$ were selected for the analysis. Spectral analysis was carried out by the standard Fast Fourier Technique. The spectral curves are presented in figure 14 and will be discussed for all three stations.

\section{Station 203}

The spectral peak at about 9.3 hours is the most prominent feature. This represents the uninodal wave. But in the curve for $11^{\circ} \mathrm{C}$, which is at the upper boundary of the thermocline, one can also detect a strong peak at about 3.06 hours. This represents a trinodal wave. A smaller peak appears at about 4.6 hours (binodal wave). In the 

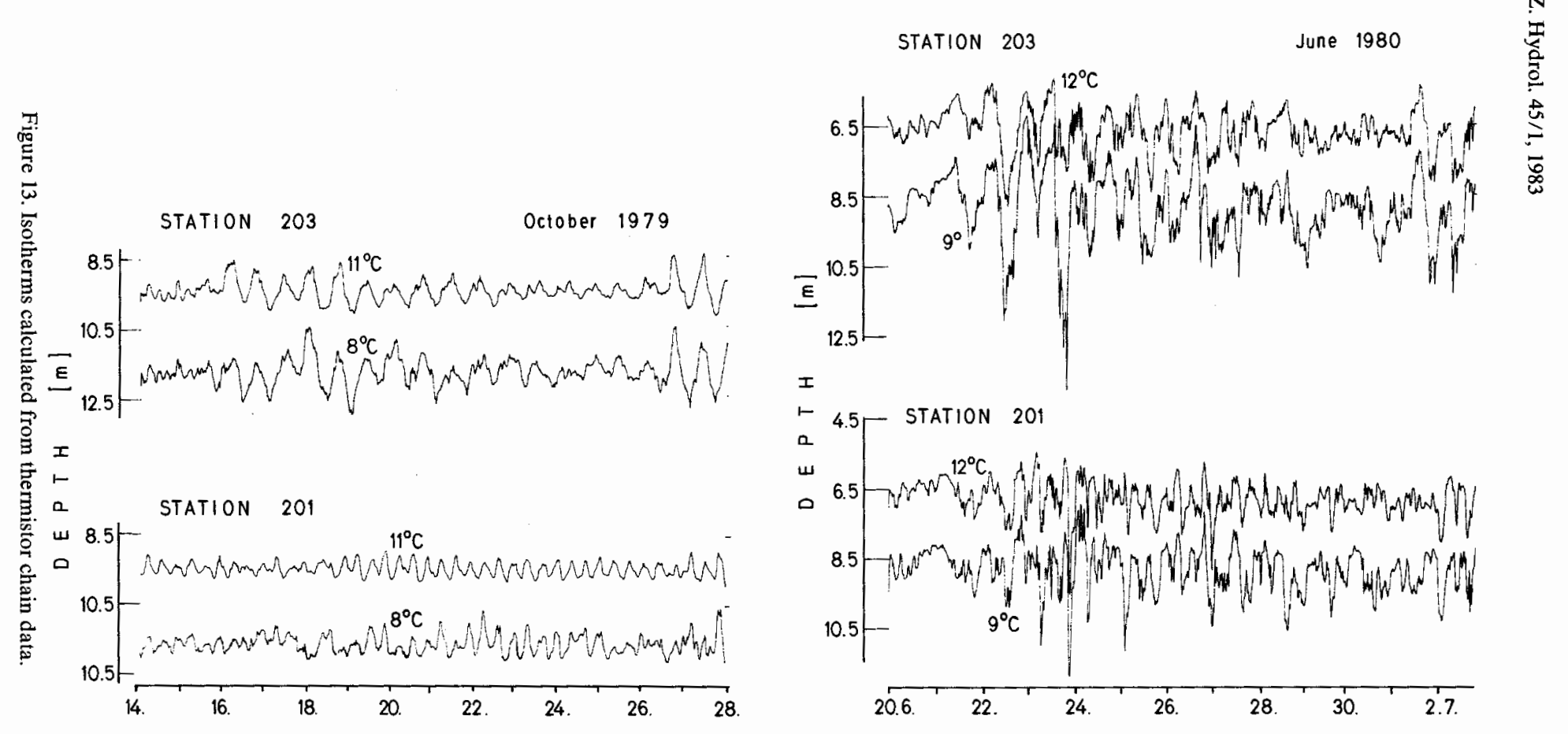


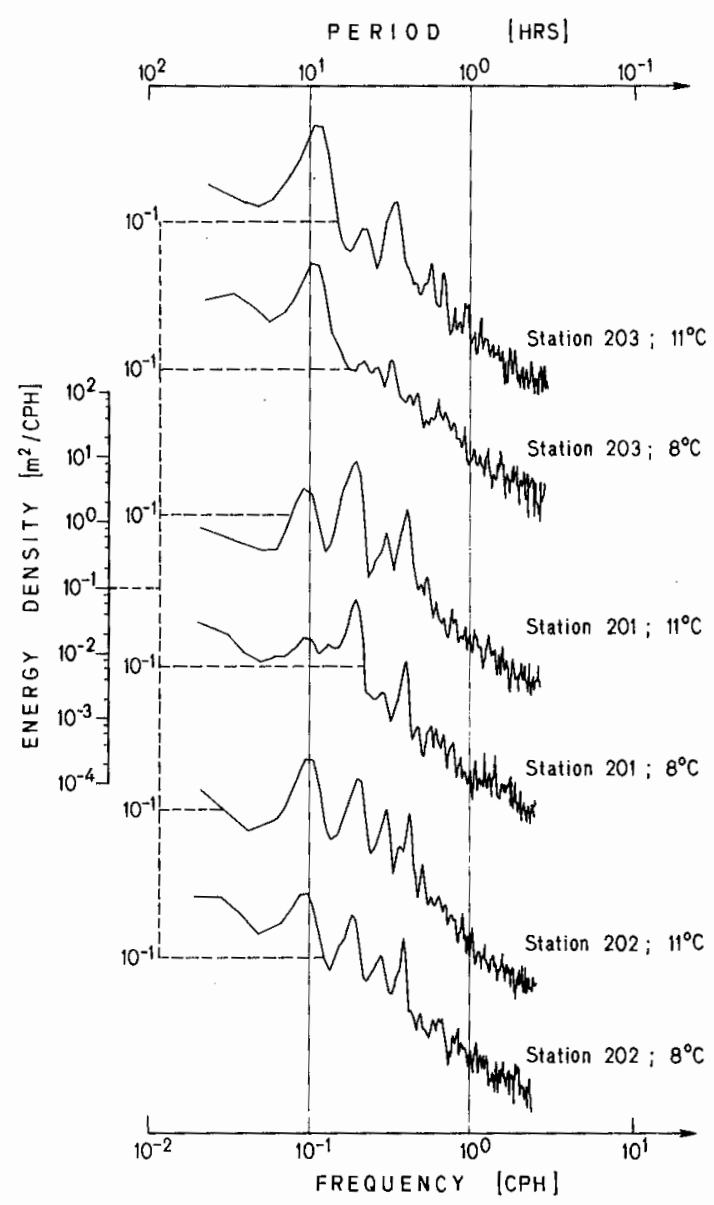

Figure 14. Isotherm energy spectra for the period from 14 October to 28 October 1979. Station number and isotherm temperature are marked on each curve.

curve for $8^{\circ} \mathrm{C}$, which is in the lower part of the thermocline, harmonics cannot be detected.

\section{Station 201}

Here the most prominent peak (period about 4.6 hours) corresponds to the binodal wave. Both curves also have a well-defined peak at period of about 2.1 hours which documents a third harmonic. The curve for $11^{\circ} \mathrm{C}$ indicates significant energy at the uninodal period because the station is obviously not exactly at the nodal point.

\section{Station 202}

Both spectral curves have peaks at the four periods which were already found in the curves of the other stations. 
Such frequency pattern has been observed throughout the period of stratification. The spectral analysis indicates that in Lake Baldegg internal waves travel more readily in the upper layer of the thermocline than in the lower one.

\section{c) Mathematical model}

Internal (two-layer) seiche analysis can be carried out using the modified Defant method [26]. For comparison with the results from the spectral analysis above, the initial conditions for the calculations were chosen to represent the mean profile for the second half of October 1979: thermocline depth $15 \mathrm{~m}$, epilimnion temperature $12{ }^{\circ} \mathrm{C}$, hypolimnion temperature $5^{\circ} \mathrm{C}$. The initial amplitudes of the wave were matched with those observed in the lake.

The calculated and the observed periods for the uninodal oscillation and the first four harmonics are given in table 4 . The agreement between the two sets of periods is quite satisfactory for the uninodal and the binodal waves. For the higher harmonics, the computed periods are slightly longer than the observed ones, but with the exception of the third harmonic, the discrepancies are below $10 \%$. Because of the simple shape of the lake basin, the shape of the wave is little altered from a sinusoidal oscillation (fig. 15, a and b).

Table 4. Comparison of calculated and observed internal wave periods.

\begin{tabular}{llll}
\hline $\begin{array}{l}\text { Wave } \\
\text { mode }\end{array}$ & $\begin{array}{l}\text { observed } \\
(\mathrm{h})\end{array}$ & Wave period & $\begin{array}{l}\text { calculated } \\
(\mathrm{h})\end{array}$ \\
\hline 1 & 9.3 & 9.34 \\
2 & 4.6 & 4.65 \\
3 & 3.06 & 3.20 \\
4 & 2.1 & 2.44 \\
\hline
\end{tabular}

The simple model can quite accurately predict the internal wave motion in Lake Baldegg. A similarly good agreement was also found by Mortimer and Horn [27] in Lake Zürich.

\section{d) Internal waves and mixing}

From the volume transport and the known cross sections of the lake, the depth averaged mean current velocities in the epilimnion and the hypolimnion of the lake can be calculated (fig. 15, $\mathrm{c}$ and d). The small difference in current speed between the two layers points towards low shear and thus decreases the wave damping. This explains why internal waves in Lake Baldegg can persist for such a long time. In the epilimnion these currents are of little interest, since other motions usually are of more importance.

In the hypolimnion the computed mean current speeds are fairly small, particularly the contributions from the harmonics. Since internal waves have been observed during most of the stratification period however, the horizontal transport which 

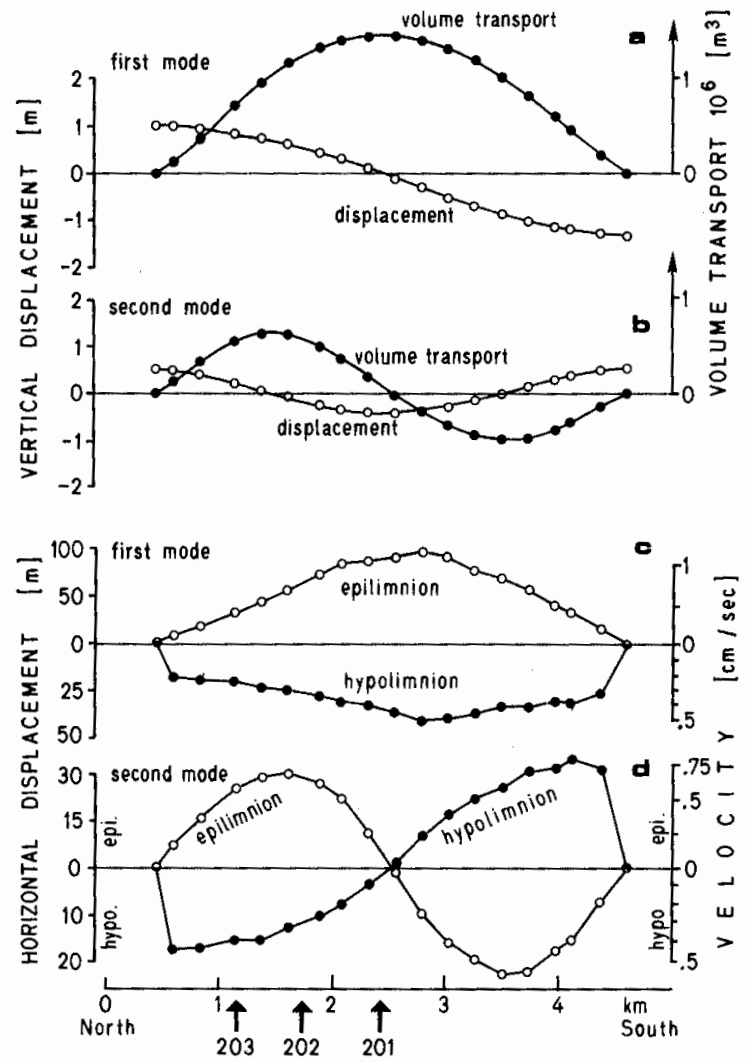

Figure 15. Defant model calculation for the first (uninodal) and the second (binodal) internal seiche mode in a two-layer model of Lake Baldegg. Interface depth: $15 \mathrm{~m}$; epilimnion temperature: $12^{\circ} \mathrm{C}$; hypolimnion temperature: $5^{\circ} \mathrm{C}$. Arrows on the bottom indicate the position of thermistor chain stations along the lake axis.

they continuously generate over a period of several months, exerts an influence on the mixing in the hypolimnion.

\section{Bottom currents}

So far little is known about currents in the hypolimnion except that they tend to be small. In an analysis of the chemistry of lake sediments, Mortimer [23, 24] suggested that the current structure at the interface be investigated in order to better understand the dynamics of the nutrient flux from the sediment. With progressing eutrophication this question gains more importance, since the sediments become a nutrient source of ever increasing strength. Current measurements well above the sediment-water interface have been carried out successfully in large lakes which are more exposed to wind [7, 32]. To our knowledge, bottom currents have never been measured in a lake the size of Lake Baldegg. 


\section{EAWAG BOTTOM CURRENT METER}

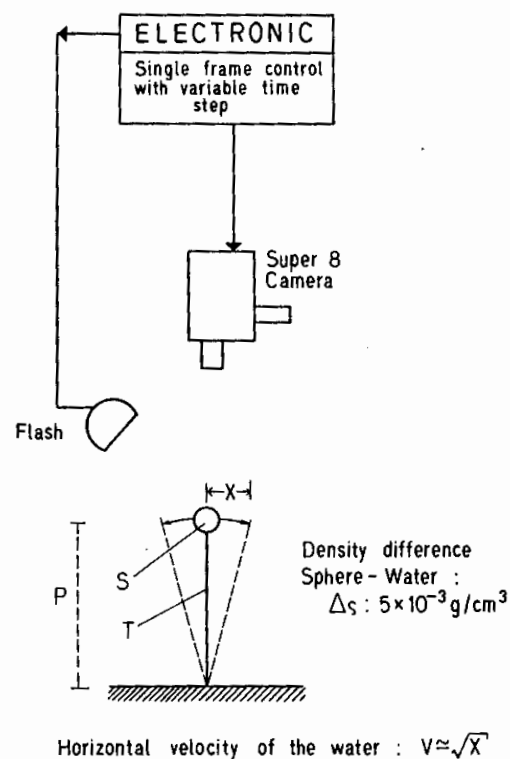

Figure 16. Bottom resting current meter. Current sensitive pendulum (P) consists of buoyant sphere (S) and light thread $(\mathrm{T} ; 0.3 \mathrm{~mm}$ diameter).

\section{a) Instrument}

Puzzled by the results of our tracer measurements (chapter 3), a study of the currents near the interface was undertaken. Since available instruments proved to be unsuitable for this investigation, a new instrument was designed. As an indicator for the current, the instrument uses an invers pendulum. A small sphere, slightly buoyant in water, is attached to a fixed platform by a very light thread. A displacement of the sphere from the rest position is a measure for the speed and direction of the current. The principle of operation is shown in figure 16.

When the instrument is placed at the bottom of the lake, the sphere (diameter $5 \mathrm{~cm}$ ) floats about $80 \mathrm{~cm}$ above the sediment on a thread of $50 \mathrm{~cm}$ length. For our application the instrument is tuned for velocities up to $2.5 \mathrm{~cm} / \mathrm{s}$. It records current sequences of about one week, with a picture taken every three minutes. A further advantage of this design is that the optical recording technique allows sediment surfaces to be observed.

\section{b) Case studies}

Two cases will be described; the first one is an example of the current pattern during stagnation, the second one of the nonstratified situation.

As has been shown in chapter 5 , during stagnation lake dynamics are dominated by internal waves at the thermocline. In the hypolimnic current records taken between 


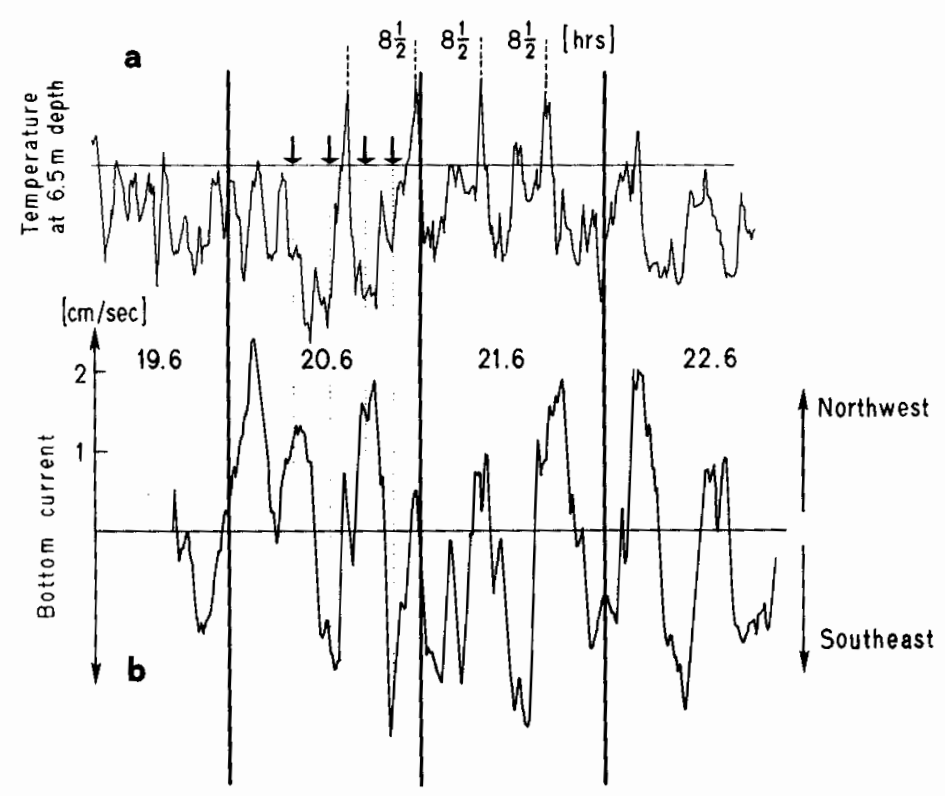

Figure 17. Temperatures and bottom currents in Lake Baldegg between 19 June and 23 June 1981. a: Temperature pattern (at station 202) in the upper part of the thermocline (6.5 m depth). Arrows indicate times of current maxima found in the bottom currents. b: Longitudinal component of bottom current.

19 June and 23 June 1980 (fig. 17, b), the dominant feature is the wavelike current pattern with many reversais. On 20 June, the wave pattern found in the bottom currents can be matched quite accurately with the first mode of the internal wave pattern in the thermocline (fig. 17, a). The current maxima occur, as would be expected by theory, at the zero crossings. The maximum current speed in this interval is about $2.5 \mathrm{~cm} / \mathrm{s}$. This is above the speed predicted by the Defant model (fig. 15). Similar wavelike current patterns have been observed in several records taken during stagnation. No immediate influence of the wind on the current pattern could be traced in these records.

The second example is a current observation taken in December 1980. During this period, the lake was only weakly stratified (fig. 18). Between 23 December and 2 January, several strong wind situations can be identified (fig. 18, a) during which winds follow the lake axis. Their effect on the lake is documented in a time-delayed downward motion of the isotherms (fig. 18, c) and a homogenization of the near surface water temperature regime (fig. 18, b). The progressive vector diagram for the bottom currents during this period is shown in figure 19. Each mark along the curve represents a 12-hour interval. The currents tend to be along the lake axis with some reversals. The path travelled during a 12 -hour interval varies greatly from nearly zero to several hundred meters. In particular, when current speeds are high, the current direction remains almost constant. 

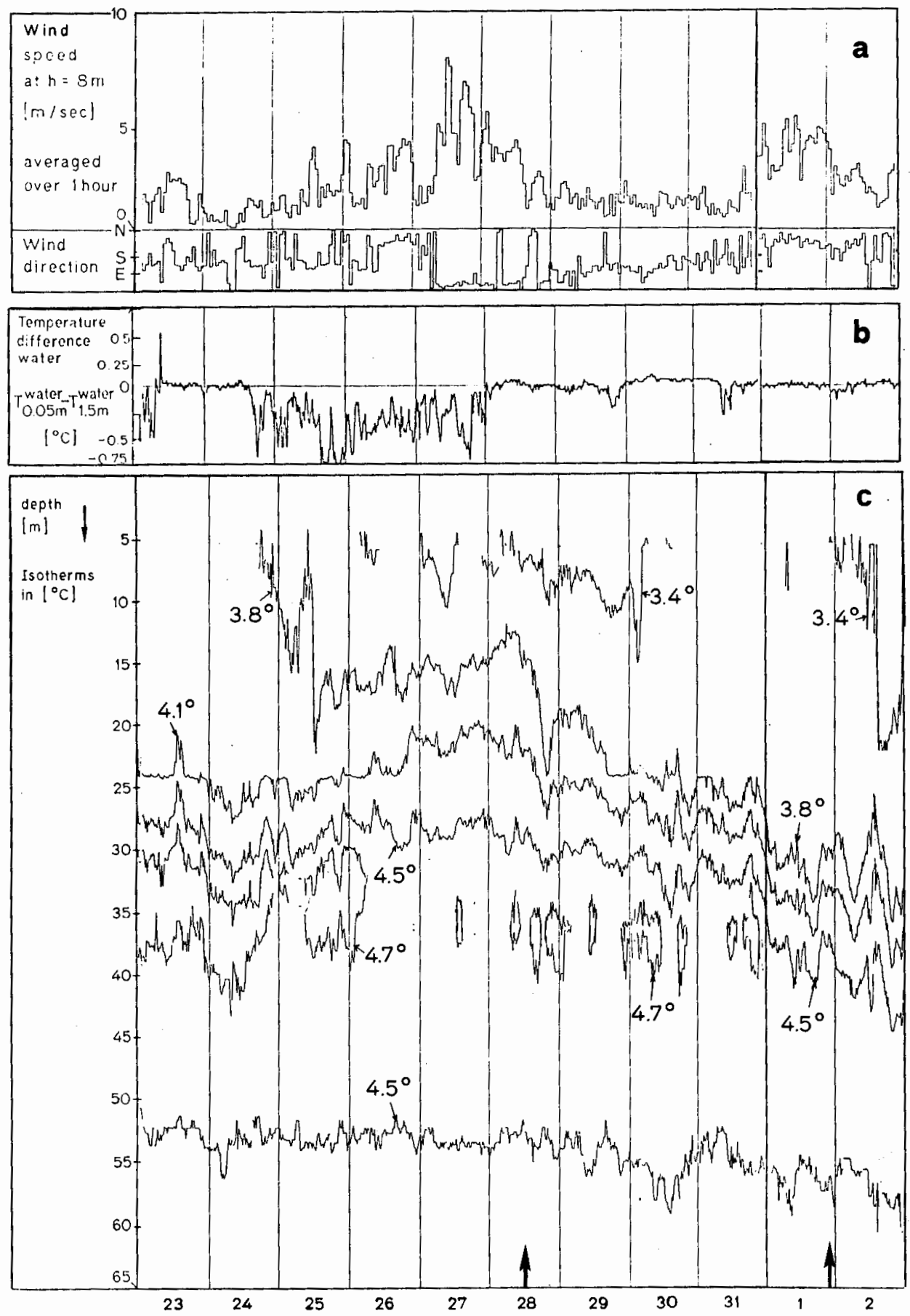

Figure 18. Measurements from meteorological buoy (station 102) in Lake Baldegg for period 23 December 1980 to 3 January 1981.

a: Wind at $8 \mathrm{~m}$ height and wind direction. Both averaged over 1 hour.

$\mathrm{b}$ : Temperature difference between $0.05 \mathrm{~m}$ depth and $1.5 \mathrm{~m}$ depth.

c: Water isotherms calculated from temperature records at 2-m intervals between $4.5 \mathrm{~m}$ and $64.9 \mathrm{~m}$ depth. Sampling interval: $20 \mathrm{~min}$. Arrows indicate onset of 'particle rain' (see text). 


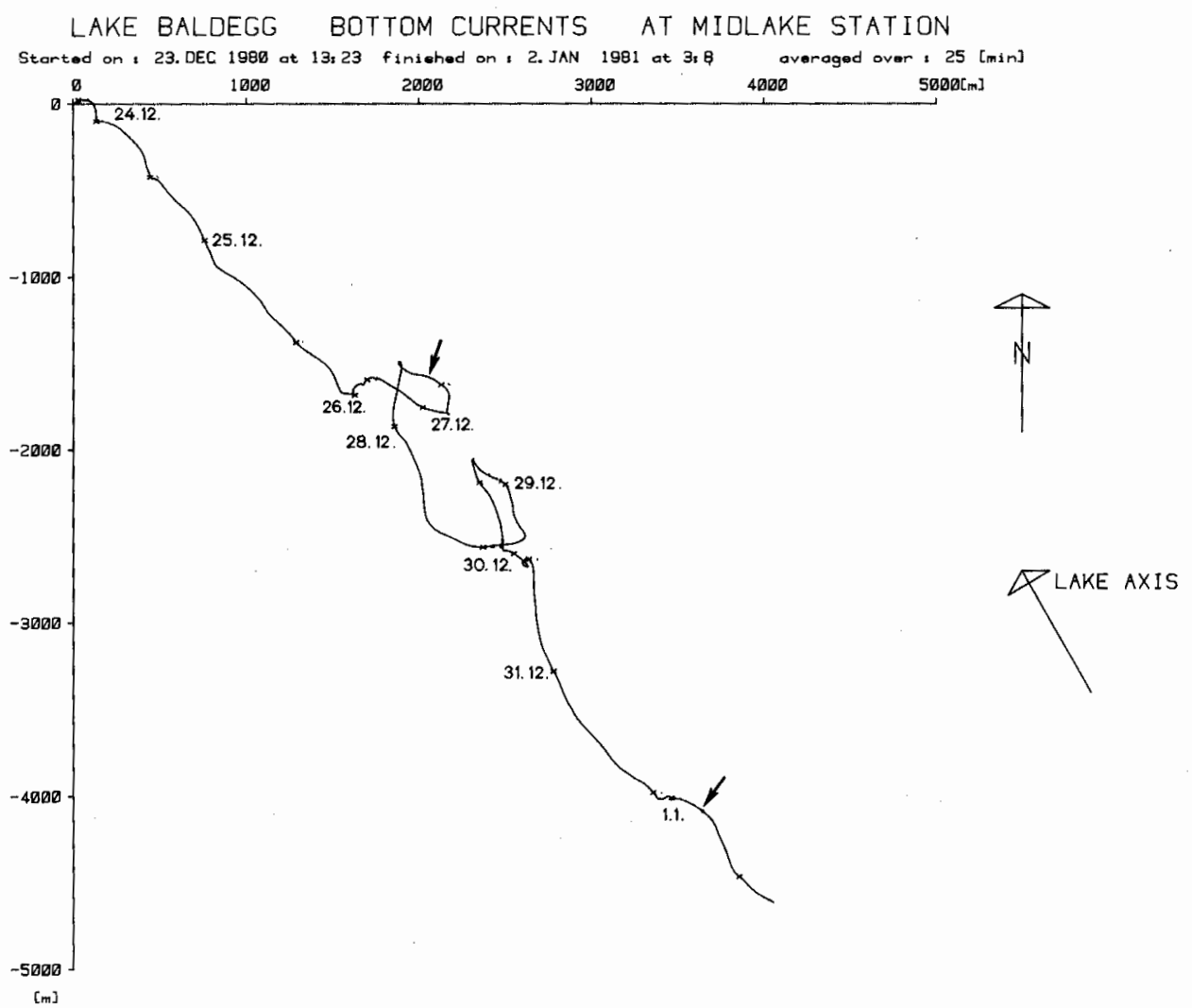

Figure 19. Progressive vector diagram of the bottom currents for the period 23 December 1980 to 2 January $1981 ; 12$-h time intervals are marked on the curve. Dates given at every second mark refer to the time of 13.31 hours. Current speeds have been averaged over five consecutive measurements. Arrows indicate onset of 'particle rain' (see text).

\section{c) Sediment-surface observations}

As was mentioned earlier, the current meter allows a visual inspection of the sediment surface. In several instances during the winter period, a heavy rain of flakes of particulate matter on to the sediment surface was observed. The flakes were about 1-2 cm long, about $0.5 \mathrm{~cm}$ wide and appeared to be flat. A typical 'rain' lasted about 1 hour; starting and ending rather abruptly. Over the next few hours the flakes gradually disappeared. Even though the chemical composition of the flakes is unknown, it is assumed that the formation of the flakes is a result of an oxidation process which occurs when aerobic surface water is entrained into the anoxic bottom water.

The times when 'particle rains' are observed, are marked in figures 18 and 19. They occur when current speeds increase. Combining all information, there seems to be evidence that the current speed rises after a strong wind. The time elapsed before the effect of the wind is felt at the bottom of the lake can only be estimated to be greater than 12 hours. 


\section{d) General results}

In several of our current records we were unable to clearly identify the source of the hypolimnic currents. With only one measuring point and an unknown path from the possible source, this was to be expected. From the inspection of all current records the following general remarks can be made:

\section{Current pattern}

Throughout the period of investigation, currents exist at all times. Their direction and strength varies with time. If the current vectors are integrated over the total length of one record and the contribution to each of eight equal compass sectors is calculated, one finds that the transport along the lake axis is always dominant. During winter, the transport pattern resembles the wind pattern (fig. 20). During summer, an almost even distribution along two directions near the lake axis supports the assumption that wavelike motion in the bottom boundary layer prevails (fig. 21).

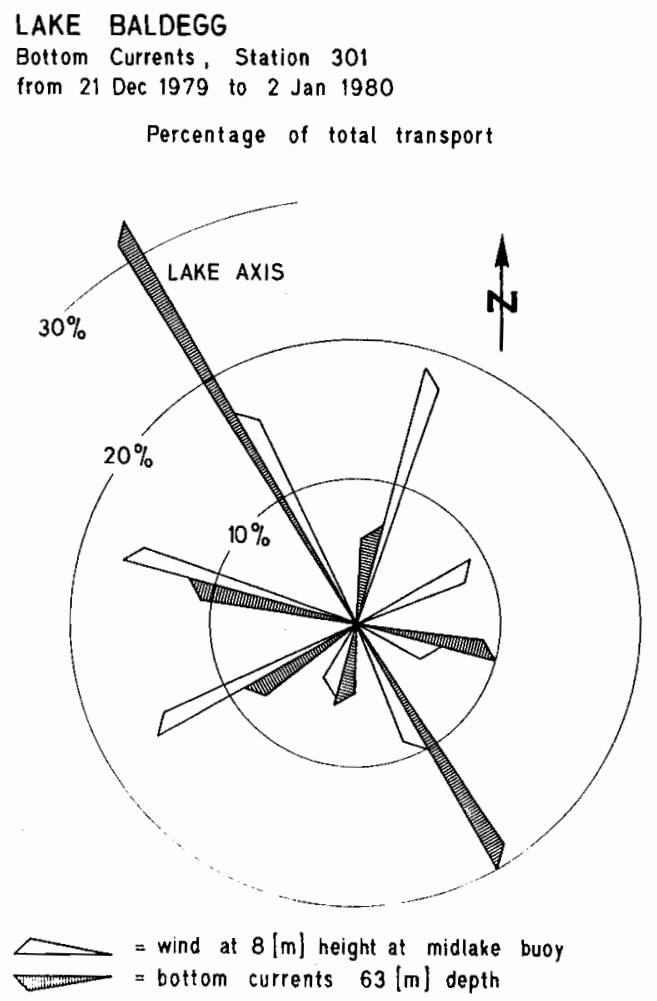

Figure 20. Percentage of total transport during the period 21 December 1979 to 2 January 1980. Wind arrows indicate transport from the direction; current arrows indicate transport into the direction. 

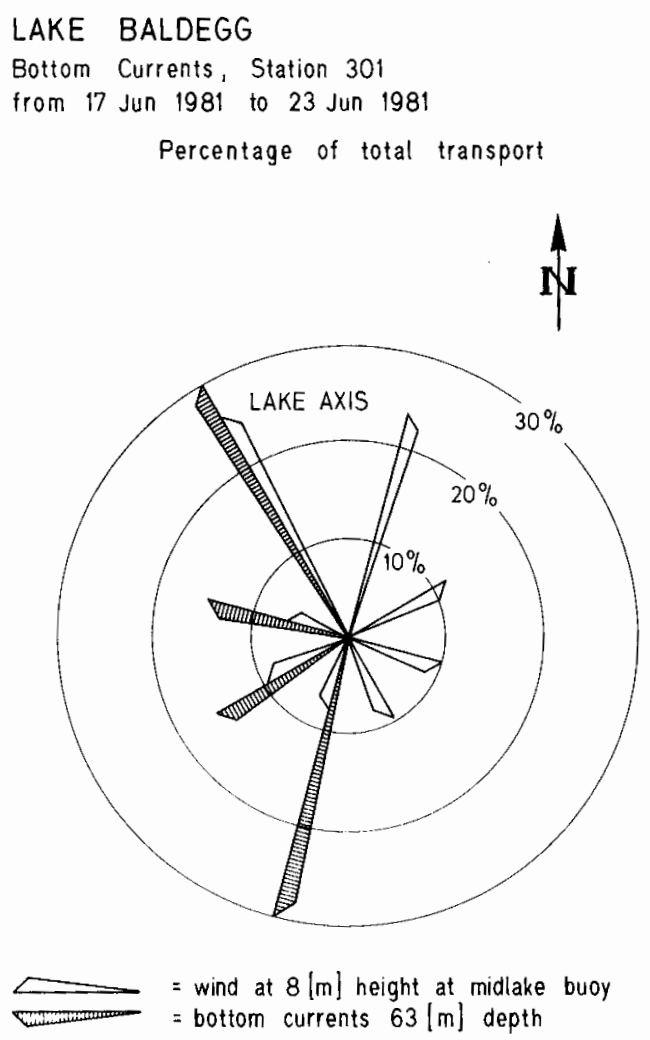

Figure 21. As figure 20 for the period $17 \mathrm{~J}$ une 1981 to 23 June 1981.

\section{Current speeds}

In the mean, the current speeds are somewhat higher in the winter $(1.8 \mathrm{~cm} / \mathrm{s})$ than in the summer $(1.2 \mathrm{~cm} / \mathrm{s})$. At all times there are situations when the current speed exceeds the capability of the instrument $(2.5 \mathrm{~cm} / \mathrm{s})$. However, even in those situations no resuspension of the sediment material is observed.

\section{Currents and mixing}

The progressive vector calculations indicate that during a one-week period a water parcel, moving along with the actual currents recorded at our site, could travel the length of the whole lake. Therefore periods of rather intensive mixing of the deep hypolimnic waters exist. These currents produce shear and generate turbulence that in part contributes to the vertical mixing.

Currents of this strength will work to erase horizontal gradients of nutrients diffusing from the sediment. In this way they may modify vertical gradients of nonuni- 
formly emanating species. One example of this are our radon measurements. As has been observed (see chapter 3 ), the scatter increases towards the sediment interface, even though the profiles were always taken at the same buoy station.

\section{Summary and conclusions}

At the beginning of this research stood the observation that vertical mixing would play a key role for the evolution of chemical and biological processes in lakes. Therefore we began to determine vertical eddy diffusivity using natural tracers. Trying to interpret the results, we realized the importance of horizontal processes such as internal waves and bottom currents. While the assessment of ecological relevance was not altered, the tools were adapted to a better understanding. Though more data still await detailed interpretation, some conclusions can be drawn. They primarily refer to Lake Baldegg, but we believe that they are typical for many small to medium sized Swiss lakes, i.e. for those lakes particularly hit by eutrophication.

1. Since input of kinetic energy by inlets is small, mixing in the lake is mainly driven by wind and heat exchange at the surface. During most of the year, thermally and chemically induced density stratification prevents the energy input from penetrating into greater depths. Instead, part of the energy is trapped in internal waves running along the thermocline with little damping.

2. As meteorological forces are highly transient in nature, so is mixing in the surface layer. During warm and calm days, strong temperature gradients develop in this layer. These gradients are eroded by diurnal convective turbulence or wind induced turbulence.

3. Internal waves dominate the internal dynamics during stratification. Though calculations of vertical eddy diffusivities show that transport of mass across the thermocline is inhibited, internal waves seem to be an important mechanism for kinetic energy transfer to the hypolimnion. The coherence between internal seiching and periodicities in the bottom currents supports this point. The indirect nature of energy transfer makes hypolimnion mixing less sensitive to meteorological forcing as long as stratification is well-developed and winds are not too strong. In contrast, when vertical density gradients become weak, direct coupling between wind forces and mixing at all depths is observed. Response time increases with depth.

4. Interpretation of short-living tracer distributions (radon-222) in the hypolimnion is complicated by horizontal bottom currents. In contrast, profiles of conservative tracers are less sensitive to advection; the shape of these profiles is given mainly by the lake topography. As the flux of phosphorus and other species across the thermocline is determined by the product of vertical concentration gradient and eddy diffusion, estimation of the internal loading becomes difficult. Nonetheless, the conclusion is corroborated that internal loading is very significant in Lake Baldegg.

5. Water ages, traced by helium and tritium, question the idea that as far as vertical mixing goes, stagnation and circulation are two well-distinguishable states of the lake. Renewal of deep hypolimnic water is neither zero during summer nor very large in winter. Instead there seems to exist a gradual transition from summer conditions (rate of replacement of water of $10-15 \%$ per month) to winter (rate of 
exchange 25 to $30 \%$ per month). Even when the lake becomes homothermal in winter, a chemically induced density gradient still reduces mixing below $40 \mathrm{~m}$. Artificial destratification, initiated in winter of 1982 as an internal measure for lake restoration, has meanwhile destroyed this chemocline in Lake Baldegg.

We believe to have identified the forces involved in hypolimnic mixing. However, since we do not yet fully understand its structure, we cannot express its coupling to the meteorological forces in mathematical terms. As Imberger and Hamblin [8] have stated recently, 'vertical mixing in the hypolimnion with special emphasis on the relative role of boundary mixing, internal mixing and mass transfer by double diffusive processes' belongs to the large gaps in our understanding of lakes. A new set of more sensitive instruments may help us to advance our knowledge in this field.

\section{ZUSAMMENFASSUNG}

Mischungsyorgänge in Seen: Mechanismen und ökologische Bedeutung

Mischungsprozesse in Seen finden auf einer breiten Skala von Längen- und Zeitmaßstäben statt. Für die Entwicklung aquatischer Ökosysteme ist dabei die vertikale Mischung von besonderer Bedeutung. In einer Langzeitstudie im Baldeggersee, einem hocheutrophen Schweizer See (Oberfläche $5,3 \mathrm{~km}^{2}$, grösste Tiefe $66 \mathrm{~m}$ ), wurde die Dynamik physikalischer Parameter (Meteorologie, Wassertemperatur, Bodenströmung) mit verankerten Messgeräten erfasst. Gleichzeitig wurden Profile natürlicher Isotope (Radon-222, Tritium und Helium-3) sowie chemischer Parameter (Phosphor, Methan, Sulfid, Ammonium und andere) genommen. Die Analyse der Daten zeigt: 1. Im Hypolimnium ist die vertikale Mischung klein. Dadurch gewinnt im tiefen Hypolimnium die Bodentopographie entscheidenden Einfluss auf die vertikale Konzentrationsverteilung sedimentbürtiger Stoffe. 2. Die Eneuerung von Tiefenwasser findet auch während der Stratifizierung statt. 3. Interne Wellen bestimmen während der Stratifizierung die interne Dynamik des Sees. 4. Horizontale Strömungen am Seegrund, die sich mit den internen Wellen korrelieren lassen, beeinflussen entscheidend die Mischung im Hypolimnion.

\section{RÉSUMÉ}

Processus de mélange dans des lacs: mécanismes et signification écologique

Une étude à long terme a été faite dans le lac de Baldegg, un lac suisse très eutrophe, d'une superficie de $5,3 \mathrm{~km}$ et d'une profondeur maximale de $66 \mathrm{~m}$. Des paramètres physiques ont été pris par une série d'instruments ancrés (météorologie, température de l'eau, courants de fond). En même temps, le profil des isotopes naturels (radon-222, tritium et hélium-3) ainsi que des paramétres chimiques (phosphore, méthane, sulfure, ammonium et autres) ont été mesurés. L'analyse des données montre: 1. Le mélange vertical dans l'hypolimnion est faible. Par ce fait, dans l'hypolimnion profond, la distribution verticale de la concentration des matières chimiques provenant du sédiment est largement influencée par la topographie du fond. 2. Le renouvellement de l'eau profonde a aussi lieu pendant la stratification. 3. Des vagues internes déterminent la dynamique interne du lac pendant la stratification. 4 . Des courants de fond horizontaux jouent un rỏie important dans le mélange de l'hypolimnion et peuvent être corrélés aux vagues internes pendant la stratification.

\section{REFERENCES}

1 Ambühl, H.: Heutiger Zustand und zukünftige Entwicklung der Alpenrandseen. In: Jahrbuch für Umweltschutz. Keller, Luzern 1973.

2 Broecker, W.S.: An application of natural radon to problems in ocean circulation. In: Ichiye, T. (ed.): Diffusion in oceans and fresh waters, p. 116-145. Lamont Geol. Obs. (1965). 
3 Craig, H., and Turekian, K.K.: The GEOSECS Program: 1976-1979. Earth planet. Sci. Lett. 49, 263-265 (1980).

4 EAWAG: Data set from Lake Baldegg; description of systems, figures and tables (1983).

5 EAWAG: Wärmepumpen an Oberflächengewässern. Schriftenreihe des Bundesamtes für Energiewirtschaft, Studie Nr.19, 82 p. Bern 1981.

6 Forel, F.A.: Le Léman: Monographie limnologique, vol. 1 (1892), 539 p., vol. 2 (1895), 651 p., vol. 3 (1904), 715 p. F. Rouge, Lausanne.

7 Hollan, E.: Strömungsmessungen im Bodensee. Sechster Bericht der AWBR, Teil 6, p. 112-187 (1974).

8 Imberger, J,, and Hamblin, P.: Dynamics of lakes, reservoirs and cooling ponds. A. Rev. Fluid Mech. (1981).

9 Imboden, D.M.: Limnologische Transport- und Năhrstoffmodelle. Schweiz. Z. Hydrol. 35, 29-64 (1973).

10 Imboden, D. M.: Phosphorus model of lake eutrophication. Limnol. Oceanogr. 19, 297-304 (1974).

11 Imboden, D.M.: The impact of pumped storage power operation on the vertical temperature structure in a deep lake: A mathematical model. In: Clugston, J.P. (ed.): Proc. 5th Pumped Storage Workshop, Clemson, S.C. (May 1979), p. 125-146 (1980).

12 Imboden, D.M.: Tracers and mixing in the aquatic environment. Habilitation thesis, Swiss Federal Institute of Technology, Zürich, 137 p. (1981).

13 Imboden, D.M., Eid, B.S.F., Joller, T., Schurter, M., and Wetzel, J.: MELIMEX, an experimental heavy metal pollution study: Vertical mixing in a large limno-corral. Schweiz. Z. Hydrol. 41, 177189 (1979).

14 Imboden, D. M., and Emerson, S.: Natural radon and phosphorus as limnologic tracers: Horizontal and vertical eddy diffusion in Greifensee. Limnol. Oceanogr. 23, 77-90 (1978).

15 Imboden, D.M., and Gächter, R.: A dynamic model for trophic state prediction. Ecol. Modelling 4, 77-98 (1978).

16 Imboden, D.M., and Joller, T.: Turbulent mixing in the hypolimnion of Lake Baldegg (Switzerland) traced by natural radon-222. To be published (1983).

17 Imboden, D.M., Lemmin, U., Joller, T., Fischer, K.H., and Weis, W.: Lake mixing and trophic state. Verh, int. Verein. Limnol, 21, 115-119 (1981).

18 Jassby, A., and Powell, Th.: Vertical patterns of eddy diffusion during stratification in Castle Lake. Limnol. Oceanogr. 20, 530-543 (1975).

19 Joller, T.: Untersuchungen vertikaler Mischungsprozesse mit chemisch-physikalischen Tracern im Hypolimnion des eutrophen Baldeggersees. Diss. ETH Zürich, in preparation (1983).

20 Li, Y.H.: Vertical eddy diffusion coefficient in Lake Zürich. Schweiz. Z. Hydrol. 35, 1-7 (1973).

21 Lietzke, T.A., and Lerman, A.: Effects of bottom relief in two-dimensional oceanic eddy diffusion modeis. Earth planet. Sci. Lett. 24, 337-344 (1975).

22 Lohri, F.: Untersuchung der Zuflüsse des Baldeggersees. Bericht z.H. des Schweiz. Bundes für Naturschutz (SBN) und des Kantonalen Amtes für Gewässerschutz, Luzern, 68 p. (1977).

23 Mortimer, C.H.: The exchange of dissolved substances between mud and water in lakes. I. The distribution of some physical variables and concentrations of dissolved substances in Esthwaite Water, April 1939-February 1940. J. Ecol. 29, 280-312 (1941).

24 Mortimer, C.H.: The exchange of dissolved substances between mud and water in lakes. IV. General discussion. J. Ecol. 30, 168-201 (1942).

25 Mortimer, C.H.: The resonant response of stratified lakes to wind. Schweiz. Z. Hydrol, 15, 94-151 (1953).

26 Mortimer, C. H.: Strategies for coupling data collection and analysis with dynamic modelling of lake motions, p. 183-277. In: Graf, W.H. and Mortimer, C.H. (ed.): Lake Hydrodynamics. Proc Symp., Lausanne, Switzerland, Oct. 1978. Elsevier Dev. Water Sci, 11, Amsterdam 1979.

27 Mortimer, C.H., and Horn, W.: Internal wave dynamics and their implication for plankton biology in the Lake of Zürich. Vjschr. natf. Ges. Zürich 127 (4), 299-318 (1982).

28 National Academy of Science (NAS): Eutrophication; causes - consequences - correctives. Proc. Symp. Madison, Wisc. 661 p. Inne 1969.

29 Nyffeler, U.P., Schindler, P.W., Wirz, U.E., and Imboden, D.M.: Chemical and geochemical studies of Lake Biel. II. A chemical approach to lake mixing. Schweiz. Z. Hydrol. 45, 373 (1983),

30 O'Melia, C. R.: An approach to the modeling of lakes. Schweiz. Z. Hydrol. 34, 1-34 (1972). 
31 Powell, Th., and Jassby, A.: The estimation of vertical eddy diffusivities below the thermocline in lakes. Water Resour. Res. 10, 191-198 (1974).

32 Serruya, S.: Wind, water temperature and motions in Lake Kineret: general pattern. Verh. int. Verein. Limnol. 19, 73-87 (1975).

33 Spigel, R.H., and Imberger, J.: The classification of mixed layer dynamics in lakes of small to medium size. J. Phys. Oceanogr. 10, 1104-1121 (1980).

34 Tỏrgersen, T., Top, Z., Clarke, W.B., Jenkins, W.J., and Broecker, W.S.: A new method for physical limnology - tritium-helium-3 ages - results for Lakes Erie, Huron and Ontario. Limnol. Oceanogr. 22, 181-193 (1977).

35 Vollenweider, R.A.: Scientific fundamentals of the eutrophication of lakes and flowing waters with particular reference to nitrogen and phosphorus as factors in eutrophication. Organization for Economic Cooperation and Development (OECD), DAS/CSI/68.27. Paris 1968.

36 Wedderburn, W.S.: Temperature observations in Loch Earn. With a further contribution to the hydrodynamical theory of the temperature seiche. Trans. R. Soc. Edinb. 48, 629-653 (1912).

37 Welander, P.: Theoretical forms for the vertical exchange coefficient in a stratified fluid with application to lakes and seas. Acta R. Soc. Sci. Litt. Gothob. Geophys, 1, 1-26 (1968).

38 Wirz, U.E.: Untersuchungen über vertikale Diffusionsprozesse im Bielersee. Diss. Univ. of Bern, Switzerland (1978).

Address of the authors: Swiss Federal Institute for Water Resources and Water Pollution Control (EAWAG), CH-8600 Dübendorf, Switzerland. 